\title{
Quasi-steady circulation regimes in the Baltic Sea
}

1

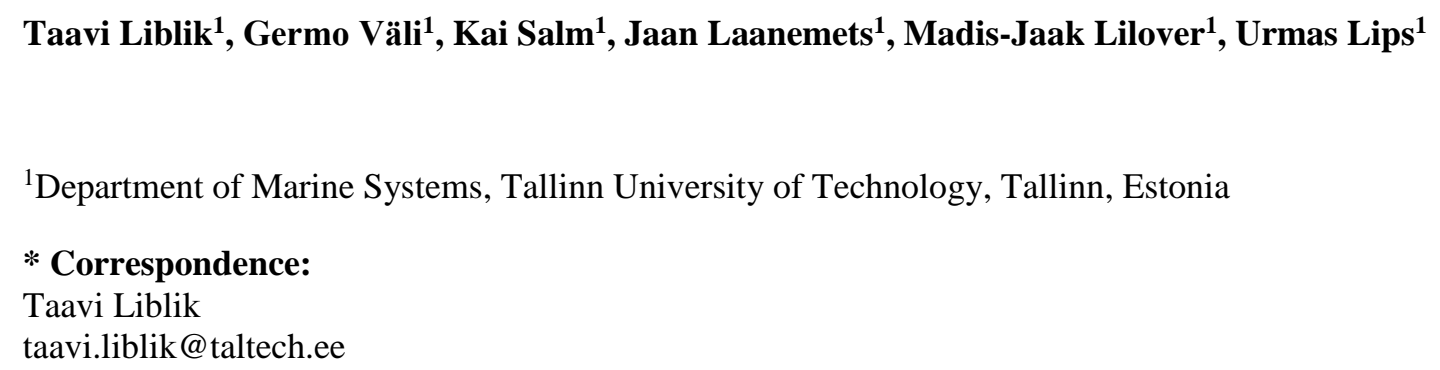

Keywords: Circulation, ADCP, underwater glider, Baltic Sea, boundary current, geostrophic current, upwelling-downwelling.

Abstract. Circulation plays an essential role in the creation of physical and biogeochemical fluxes in the Baltic Sea. The main aim of the work was to study the quasi-steady circulation patterns under prevailing forcing conditions.

Six months of continuous vertical profiling and fixed-point measurements of currents, two monthly underwater glider surveys, and numerical modelling were applied in the central Baltic Sea. The vertical structure of currents was strongly linked to the location of the two pycnoclines: the seasonal thermocline and the halocline. The vertical movements of pycnoclines and velocity shear maxima were synchronous. The quasi-steady circulation patterns were in geostrophic balance and high-persistent. The persistent patterns included circulation features such as upwelling, downwelling, boundary current, and sub-halocline gravity current. The patterns had a prevailing zonal scale of 5-60 km and considerably higher magnitude and different direction than the long-term mean circulation pattern.

Northward (southward) geostrophic boundary current in the upper layer was observed along the eastern coast of the central Baltic in the case of southwesterly (northerly) wind. The geostrophic current at the boundary was often a consequence of wind-driven, across-shore advection.

The sub-halocline quasi-permanent gravity current with a width of 10-30 km from the Gotland Deep to the north over the narrow sill separating the Farö Deep and Northern Deep was detected in the simulation, and it was confirmed by an Argo float trajectory. According to the simulation, a strong flow, mostly to the north, with a zonal scale of $5 \mathrm{~km}$ occurred at the sill. This current is an important deeper limb of the overturning circulation of the Baltic Sea. The current is stronger with northerly winds and restricted by the southwesterly winds.

The circulation regime has an annual cycle due to seasonality in the forcing. Boundary currents are stronger and more frequently northward during the winter period. The sub-halocline current towards the north is strongest in March-May and weakest in November-December. 


\section{Introduction}

Current structure is an important player in the physical and biogeochemical fluxes in ocean. The semienclosed, shallow, brackish Baltic Sea has a strong but variable vertical stratification characterized by two pycnoclines: the permanent halocline and the seasonal thermocline (Leppäranta \& Myrberg, 2009). Three-layer structure occurs in summer and consists of warm and fresh upper mixed layer, cold and saltier intermediate layer, and warmer and saltiest deep layer. Water column is mixed up to the permanent halocline at $60-80 \mathrm{~m}$ depth and cold intermediate water forms during winters. Stratification through the two pycnoclines impedes vertical mixing, and transport of substances between the layers is limited. The role of tides is marginal in the Baltic Sea. Lateral flows play an important role in distributing the water properties.

Water-mass circulation of the Baltic Sea is determined by the saline water inflow from the North Sea and freshwater input from the catchment area. The interaction of the fresher and saltier waters forms the so-called Baltic haline conveyor belt (Döös et al., 2004). The belt consists of saltier water transport and signal propagation in the deep layer towards the north-eastern end of the Baltic (Liblik et al., 2018; Väli et al., 2013); upward salt flux through vertical mixing and transport (Reissmann et al., 2009), and outflow of the mix of riverine and saltier water in the upper layer (Jakobsen et al., 2010). The conveyor determines salinity, stratification and other important characteristics for the pelagic ecosystem.

The largest basin in the sea, the Baltic Proper (Fig. 1a) is a source for the deep waters of the Gulf of Riga, Gulf of Finland and Gulf of Bothnia. Permanent oxygen depletion has expanded in recent decades in the Baltic Sea, forming one of the largest dead zones in the global ocean (e.g. Carstensen et al., 2014). Only Major Baltic Inflows (Matthäus \& Franck, 1992; Mohrholz, 2018) ventilate the deep layers of the southern and central Baltic Proper (Holtermann et al., 2017) but increase hypoxia in the Northern Baltic Proper and Gulf of Finland (Liblik et al., 2018).

59

60

The basin-scale pattern of the long-term mean circulation in the Baltic Proper is cyclonic as demonstrated by several modelling studies (Hinrichsen et al., 2018; Jedrasik et al., 2008; Jędrasik \& Kowalewski, 2019; Meier, 2007; Placke et al., 2018). The mean circulation is to the north along the eastern coast of the Baltic Proper and to the south along the eastern and western coast of Gotland Island (Meier, 2007; Placke et al., 2018). The turning area for this basin-wide cyclonic circulation cell in the north is between 59 to $59.5^{\circ} \mathrm{N}$ (Meier, 2007). The zonal center of the cyclonic flow in the Eastern Gotland Basin is in the Gotland Deep (Placke et al., 2018). The cyclonic structure exists from the bottom to the surface (Placke et al., 2018), although lateral structure and magnitude of the flow vary among different models (Placke et al., 2018). It is important to note that all forementioned descriptors of the long-term mean flow rely on numerical simulations and lack support from observations. However, a consistent northward low-frequency current along the eastern slope of the Gotland Deep at $204 \mathrm{~m}$ depth has been reported (Hagen \& Feistel, 2004). Placke et al. (2018) compared simulated currents with these measurements. All model simulations showed the mean meridional northward current velocity in the range of $0-1 \mathrm{~cm} \mathrm{~s}^{-1}$ (actually, three models out of four had values of $0.0-0.1 \mathrm{~cm}$ $\mathrm{s}^{-1}$ ) while the measurements gave the mean northward velocity of $3 \mathrm{~cm} \mathrm{~s}^{-1}$ (Hagen \& Feistel, 2004). Thus, the long-term mean flow to north in the deep layer was much stronger than the simulated mean current.

Temporal variability of currents in the Baltic Sea is very high as a reaction to atmospheric forcing. Near-shore Eulerian current observations (Sokolov \& Chubarenko, 2012) and drifter experiments 
(Golenko et al., 2017; Krayushkin et al., 2019) conducted in the southern Baltic Proper showed a strong correlation between wind and surface currents. Current velocity spectra in the Baltic include seiches and tides with different periods from $11 \mathrm{~h}$ to $31 \mathrm{~h}$ and inertial motions with a period of about $14 \mathrm{~h}$ (Jönsson et al., 2008; Lilover et al., 2011; Suhhova et al., 2018).

The vertical current structure through thermocline and halocline has not been rigorously studied by the in-situ observations in the Baltic Proper. Moreover, despite a considerable effort to reveal the spatial, long-term mean circulation patterns based on the simulations, not much has been done to study temporal developments of currents in the synoptic (mesoscale) and seasonal timescales in the Baltic Proper. In the present work, we address this shortage of knowledge.

Permanent circulation systems, such as boundary currents or subtropical gyres, are key processes that determine transport in the open ocean (e.g. Macdonald, 1998). Although there are no permanent currents in the Baltic Sea, we hypothesize that under stable wind forcing and stratification conditions, a steady circulation regime prevails in the time-scale of days to weeks and has a much greater magnitude than the mean current structures. These quasi-steady circulation features could be related to the downwelling and upwelling processes or appear as a boundary current or a gravity current under the halocline.

Following a description of the methods used, we present an analysis of (1) boundary current under variable wind forcing and stratification, (2) quasi-permanent circulation patterns, and (3) sub-halocline current. The analysis of observational and simulation results is followed by discussion and conclusions. 

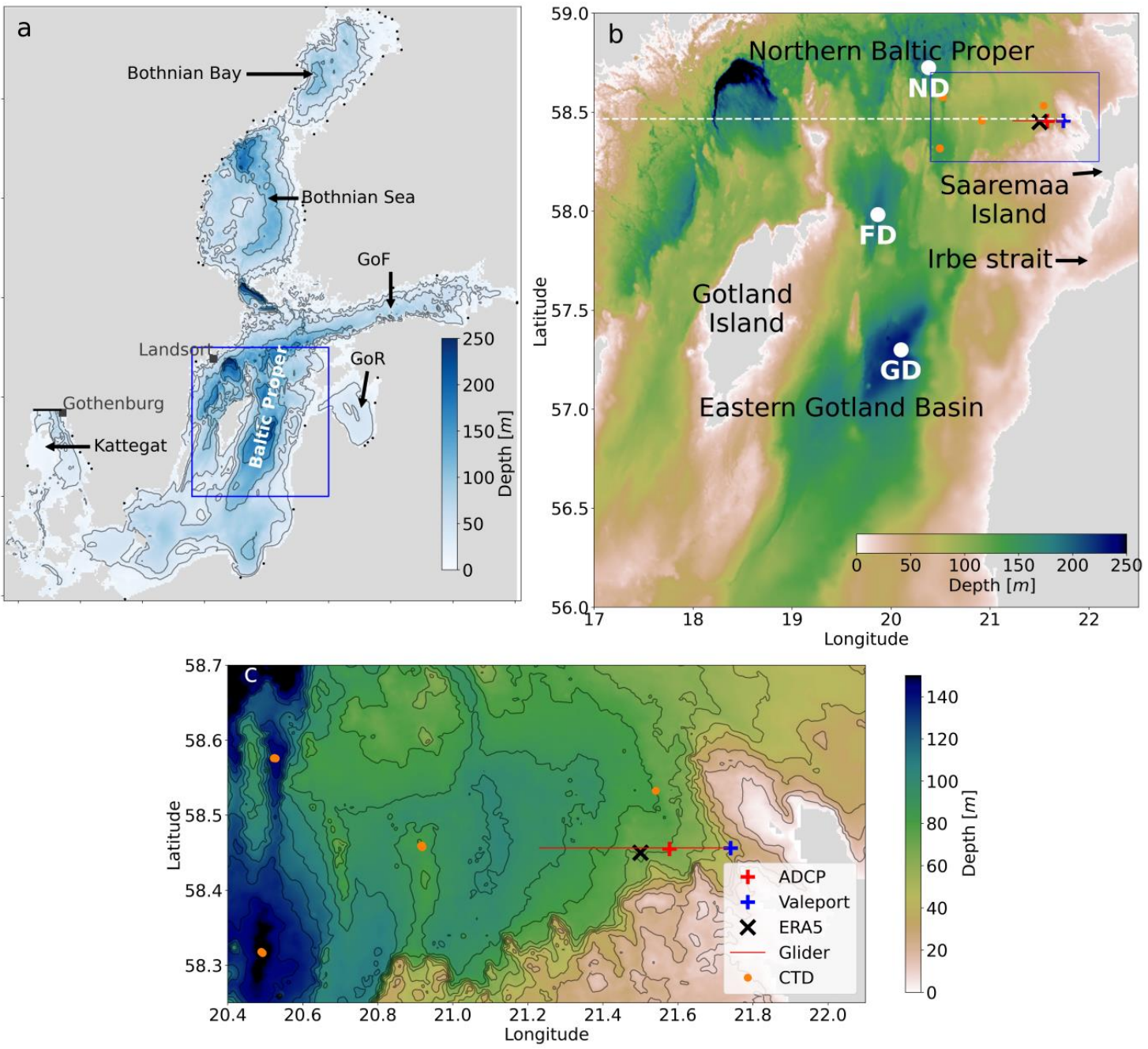

Figure 1. (a) Map of the Baltic sea and model domain. Shown are the locations of the open boundary of the model domain in the Kattegat (bold black line), Landsort and Gothenburg sea level stations, Baltic Sea rivers used in the model (black dots) and study area (black box). (b) Close-up of the study area. Locations of ADCP and Valeport moorings, CTD measurements, glider section, the center of the cell of ERA5 wind data, and zonal section along the latitude of the ADCP location in the Nortern Baltic Proper (white dashed line) are presented. Gotland Deep (GD), Fårö Deep (FD) and Northern Deep (ND) are also shown. (c) Close view of the moorings and CTD measurement locations, glider section, and local topography are shown.

\section{Data and methods}

\subsection{Observations and data products}

A bottom mounted current profiler ADCP $300 \mathrm{kHz}$ (Teledyne RDI) and model 106 current meter (Valeport Ltd) (hereinafter referred to as Valeport) were deployed at the end of February to the west of Saaremaa Island (Fig. 1b and c). Valeport was mounted at $5 \mathrm{~m}$ depth, while the sea bottom depth in its 
location was $41 \mathrm{~m}$. The sea depth in the ADCP location was $71 \mathrm{~m}$ and velocities were measured with

112 vertical depth interval of $2 \mathrm{~m}$ in the depth range of 10-68 $\mathrm{m}$. Current velocity profiles were recorded 113 as average of $1 \mathrm{~h}$. The quality of the current velocity data was checked following the procedure 114 developed by Book (et al., 2007). Valeport recorded current velocity with 10 min intervals. A Seabird 115 SBE 16Plus V2 CTD SEACAT conductivity and temperature recorder was deployed together with the 116 ADCP, but it hung $4 \mathrm{~m}$ above the sea bottom, i.e., at a depth of $67 \mathrm{~m}$. SBE 16Plus sensors were 117 calibrated by the manufacturer before the deployment.

118 Repeated CTD profiles onboard R/V Salme were collected using an OS320 CTD probe (Idronaut S.r.1.) 119 in the Northern Baltic Proper (see Fig. 1b and c) from 30 January to 4 August 2020.

120 Argo float deployment was arranged by the Finnish Meteorological Institute (Siiriä et al., 2019) from 15 August 2013 to 15 August 2014 and the trajectory data was derived from the Argo-based deep displacement dataset (Ollitrault \& Rannou, 2013). The dataset was downloaded on 15 March 2021 at https://www.seanoe.org/data/00360/47077/.

In 2020, two glider missions were conducted in the Northern Baltic Proper. The Slocum G2 Glider collected oceanographic data along the E-W oriented $27 \mathrm{~km}$ long section (Fig. $1 \mathrm{~b}$ and c). The easternmost point of the glider track was approximately $7 \mathrm{~km}$ off the shoreline and the section was located at the sloping bottom where sea depth gradually deepened westward from $40 \mathrm{~m}$ to $90 \mathrm{~m}$. The first mission was carried out from 28 February to 22 March 2020 and the second one from 4 August to 2 September 2020. Both ascending and descending profiles were recorded and altogether over 8000 profiles were gathered. The glider moved at a horizontal speed of $0.33 \pm 0.08 \mathrm{~m} \mathrm{~s}^{-1}$. On average, a profile took $8.0 \pm 0.9 \mathrm{~min}$ to complete $80-90 \mathrm{~m}$ deep profile and the average distance between the profiles near the surface was $301 \pm 46 \mathrm{~m}$. Both the sampling time and the distance were decreased by half in the shallow part of the section.

Preliminary glider data processing included the standard quality control (impossible date and location test, range tests for the sensors) and accounting for the response time of the sensors and the thermal lag. First, a linear time shift was applied to temperature and conductivity considering the misalignment with pressure. Temperature was re-aligned by $1.4 \mathrm{~s}$ and conductivity by $0.9 \mathrm{~s}$ for the mission conducted in the spring and respectively by $1.6 \mathrm{~s}$ and $1.1 \mathrm{~s}$ for the mission in the summer. The parameters were chosen by comparing consecutive profiles focusing on the depth range around the greatest gradient. It was assumed that successive profiles correspond to the same water mass. We followed Mensah et al. (2009) to remove the thermal lag effect and found optimal coefficients for the temperature error amplitude, $\alpha$, and time constant, $\mathrm{t}_{\mathrm{c}}$, by comparing consecutive TS-profiles. The satisfying results were obtained in the case of $\alpha=0.0025$ and $t_{\mathrm{c}}=10 \mathrm{~s}$ for the earlier mission and $\alpha=0.055$ and $\mathrm{t}_{\mathrm{c}}=12 \mathrm{~s}$ for the following one. The profiles were averaged on a $0.5 \mathrm{dbar}$ vertical grid after processing the raw data.

Sea surface temperature was derived from the Copernicus Marine Service product SST_BAL_SST_L4_REP_OBSERVATIONS_010_016 with a horizontal resolution of $0.02 \times 0.02$ degrees. Mean difference between the product and in-situ data sources has been in the range of -0.12 to $-0.21{ }^{\circ} \mathrm{C}$ and root mean square error from 0.43 to $0.88^{\circ} \mathrm{C}$ depending on the data sources according to the quality information document (https://catalogue.marine.copernicus.eu/documents/QUID/CMEMS-SST-QUID-010-016.pdf,

152 accessed 19 August 2021). 
Hourly, 10 m level wind velocities of ERA5 reanalysis data (Hersbach et al., 2020) at the cell with the size $0.25^{\circ} \times 0.25^{\circ}$ from 1979 to 2020 (see Fig. 1 for location) were used in the analyses.

\subsection{Modelling}

Numerical model GETM (General Estuarine Transport Model, Burchard \& Bolding, 2002) has been applied to simulate the circulation and temperature/salinity distribution in the northeastern Baltic Sea. GETM is a primitive equation, three-dimensional model with free surface and $k-\varepsilon$ turbulence model for vertical mixing by coupling the hydrodynamic part with GOTM (General Ocean Turbulence Model, Umlauf \& Burchard, 2005).

Model domain covered the whole Baltic Sea with the open boundary situated in the Kattegat region (Fig. 1a). The horizontal grid spacing of the model was 0.5 nautical miles $(926 \mathrm{~m})$ and 60 vertically adaptive coordinates (Hofmeister et al., 2010; Gräwe et al. 2015) were used. Sea surface height from Gothenburg station has been used as the boundary condition to control the barotropic in- and outflow from the Baltic Sea, while the temperature and salinity were nudged towards monthly climatological profiles (Janssen et al., 1999) along the open boundary.

Data from the Estonian version of the operational model HIRLAM (High Resolution Limited Area Model) maintained by the Estonian Weather Service and giving forecasts with hourly resolution (Männik and Merilain, 2007) were used to calculate the momentum and heat flux at the sea surface. Climatological runoff of the Baltic Sea rivers with inter-annual variability added from the values reported to the HELCOM (Johansson, 2016) was used. Simulation covered period from April 2010 to September 2020, and initial temperature and salinity fields were taken from the CMEMS (Copernicus Marine Service) re-analysis product for the Baltic Sea.

The same setup of the model was previously used in Zhurbas et al., (2018) and Liblik et al. (2020) and more details about the model setup are given there. Zhurbas et al. (2018) validated the salinity and temperature values in the central Baltic Sea along with the sea surface height at Landsort station and compared the near-bottom current statistics with the long-term observations in the Gotland Deep. Liblik et al. (2020) validated the simulated wintertime sea surface temperature and salinity in the Gulf of Finland and compared the observed mixed layer depth with the simulations. In this study, we will present the comparison of simulated and observed currents in the Northern Baltic Proper.

\subsection{Calculations}

Isohaline $9 \mathrm{~g} \mathrm{~kg}^{-1}$ was selected to define the center of the halocline $(\mathrm{CH})$ depth since the halocline was steepest around this salinity value according to the salinity profiles. To estimate the center of halocline depth based on single level salinity time-series measured by the SBE 16Plus, and twelve CTD profiles collected by the RV Salme in the Northern Baltic Proper (see Fig. 1b) from 30 January to 4 August 2020 were used. Salinity profiles were vertically normalized by subtracting the depth of the $\mathrm{CH}$ at each profile. Next, the mean salinity profile in the normalized depth coordinates was calculated (Fig. 2). The mean normalized depth and salinity relationship were used to derive the $\mathrm{CH}$ depth from the SBE 16Plus salinity time-series at $67 \mathrm{~m}$ depth. If salinity was lower (higher) than $9 \mathrm{~g} \mathrm{~kg}^{-1}$, the $\mathrm{CH}$ was deeper (shallower) than $67 \mathrm{~m}$ according to the mean depth-salinity curve (Fig. 2). Maximum depth of the neighboring sea area, $88 \mathrm{~m}$, was defined as the maximum depth of the $\mathrm{CH}$. 
In this study the $x$-axis is positive eastward, the $y$-axis is positive northward, and the $z$-axis is positive upward ( $z=0$ at the sea surface), $u$ and $v$ are horizontal velocity components.

The baroclinic components of the geostrophic velocity $\left(u_{g}\right.$ and $v_{g}$ ) can be deduced from the hydrographic data. Considering the dynamic method, the geostrophic relationships are as follows

$v_{g}=\frac{1}{f} \frac{\partial \Phi}{\partial x}$

$u_{g}=-\frac{1}{f} \frac{\partial \Phi}{\partial y}$

The geopotential, $\Phi$, is proportional to the dynamic height, $\mathrm{D}$, as

$\Phi=\mathrm{gD}$

where $g$ is the gravitational acceleration and $f$ is the Coriolis parameter.

The dynamic height can be determined from the temperature and salinity (density) profiles.

The relative geostrophic velocity was evaluated using dynamic height anomaly relative to a reference pressure (McDougall \& Barker, 2011). The geopotential slope of an isobaric surface expresses the horizontal pressure gradient. A zonal glider track enabled to calculate the meridional velocity profile of the geostrophic flow. The meridional geostrophic velocity was calculated also from the GETM simulation data. The reference level was set at $70 \mathrm{dbar}$. The shallower profiles were included using the stepped no-motion level method described in Rubio et al. (2009). Since velocity is not zero at the 70 dbar level, the calculated geostrophic velocities $V_{\text {GEO-DENS-glider }}$ and $V_{\text {GEO-DENS-GETM }}$ described in subchapter 3.1 represent relative velocities to the no-motion $70 \mathrm{dbar}$ level. Both variables represent an averaged velocity at an extent of $10 \mathrm{~km}$ zonal scale around ADCP position.

To compare the simulated geostrophic velocity profiles with the measured ADCP velocity profiles, the relative geostrophic velocity at the sea surface (calculated relative to 70 dbar using simulated density profiles) was aligned with the geostrophic velocity due to the sea level gradient from the model

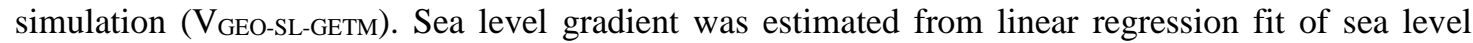
anomalies at a horizontal scale of $10 \mathrm{~km}$. The difference (vector) between the density-estimated and the sea level estimated geostrophic velocity at the sea surface was applied to the whole geostrophic velocity profile under the assumption that the geostrophic current at the surface is determined by the differences in the sea level exclusively. Adjusted geostrophic velocity profiles were presented as $\mathrm{V}_{\mathrm{GEO}}$ ADJ-GETM in subchapter 3.2. 


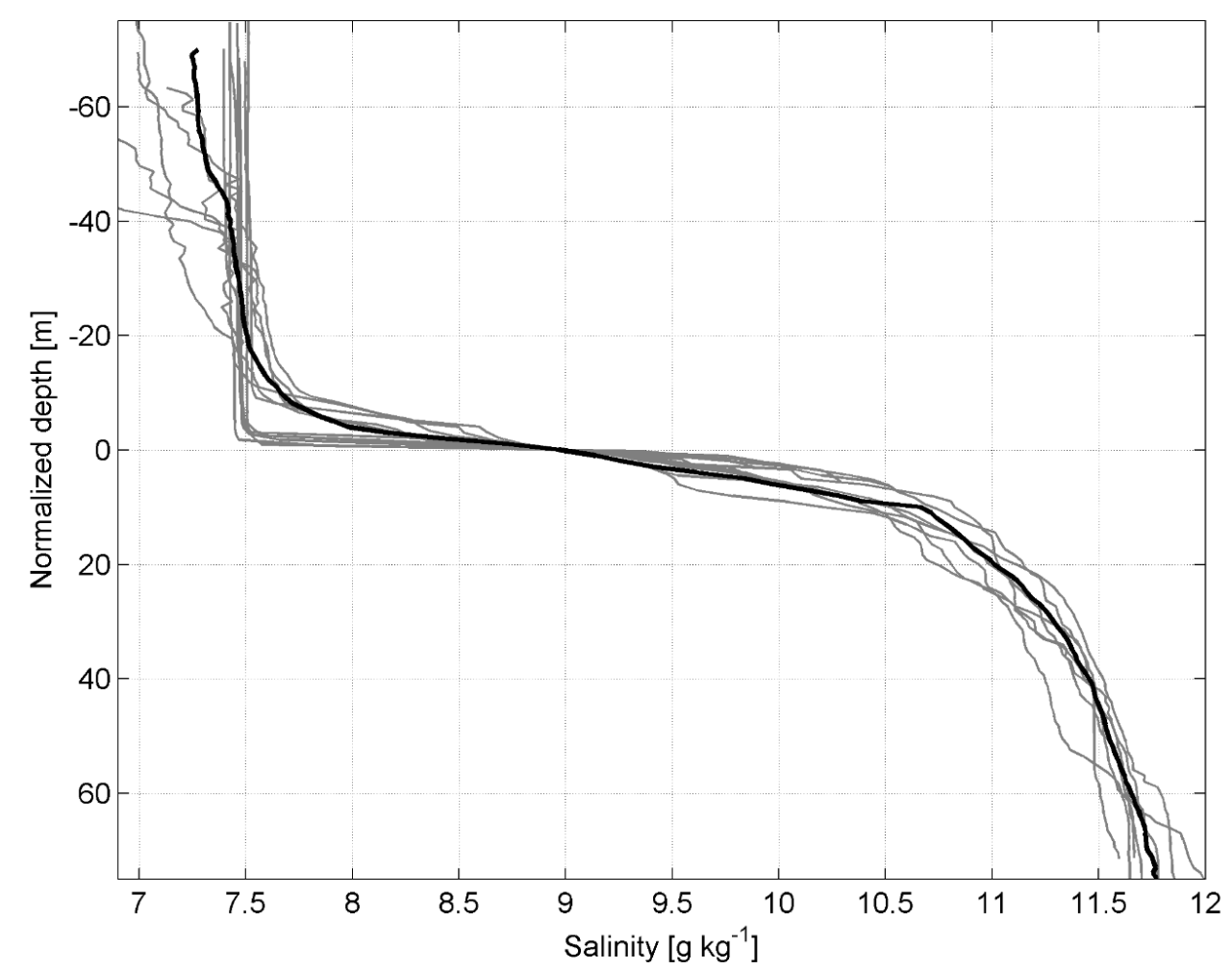

Figure 2. Vertically normalized salinity profiles from 30 January to 4 August 2020 in the Northern Baltic Proper (see Fig. 1b). Bold black line represents the mean salinity profile.

The direct influence of wind forcing on the subsurface currents was ascertained using the classical Ekman model based on the balance of the frictional and Coriolis forces (Ekman, 1905). Wind stress vector $\tau$ as the Ekman model input parameter was calculated using ERA5 (Fig. 1b and c) wind data: $\tau$ $=\rho_{\text {air }} \mathrm{cd}|\mathbf{U}| \mathbf{U}$, which were prior low-pass filtered with cut-off 36 hours to exclude periodic processes. Here $\mathbf{U}$ is the wind velocity vector at $10 \mathrm{~m}$ height, $\mathrm{cd}$ is the drag coefficient and was parameterized as proposed by $(\mathrm{Wu}, 1980)$ : $\mathrm{cd}=(0.8+0.065|\mathbf{U}|) \times 10^{-3},|\mathbf{U}|$ is the wind velocity vector module and $\rho_{\text {air }}$ is the density of air. The eddy viscosity used in the model was calculated according to (Csanady, 1981): $v=|\tau| / 200 f$, where $|\boldsymbol{\tau}|$ is the wind stress vector module. The model outputs are the vertical profiles of wind-induced current velocity components.

234 The temporal development in the vertical current structure is presented as the time-series of vertical current shear squared $s^{2}=(\partial u / \partial z)^{2}+(\partial v / \partial z)^{2}$.

236 Persistency of the current is defined as the ratio between vector and scalar current speeds:

$$
R=\frac{\sqrt{u^{2}+v^{2}}}{\frac{1}{N} \Sigma \sqrt{u_{n}^{2}+v_{n}^{2}}}
$$


Current and wind velocity components are presented as 36-h and 10-day low-passed time-series. The fourth-order Butterworth filter was used for low-pass filtering.

\section{$2413 \quad$ Results}

\subsection{Boundary current under variable wind forcing}

Statistics of the 6 months (1 March-1 September 2020) ADCP deployment revealed the persistency of currents between 32 and $42 \%$, with the highest persistency in the 20-40 m depth range (Table 1). Mean and maximum hourly measured speeds were higher in the uppermost bin at $11 \mathrm{~m}$ depth, 11 and $48 \mathrm{~cm}$ $\mathrm{s}^{-1}$, respectively and lower in the near-bottom layer, 7 and $34 \mathrm{~cm} \mathrm{~s}^{-1}$. The mean $u$ - and $v$-components were positive in all depths showing the mean flow to the NE sector.

From the flow structure point of view the ADCP current velocity time series can be divided into two periods: 1) from March until mid-April, when barotropic regime prevailed, 2) from mid-April until September, when layered flow dominated (Fig. 3a and b). One can also see the coincidence of the current $u$ - and $v$-components in the uppermost and deepest bin during the first period (Fig. $3 \mathrm{c}$ and d) except a short period at the end of March. Discrepancies between the two layers afterwards illustrated the layered, baroclinic nature of the flow. The flow regime reacted well to wind forcing. Barotropic flow to the northeast prevailed as a result of southwesterly winds until mid-April (Fig. 4). Only during the last week of March, when wind was from northerly directions, a strong southerly current was observed. Similar temporal patterns appeared in the upper layer in the stratified period. Alteration of positive and negative meridional velocities was related to the prevailing wind direction. These tendencies were evident both in the ADCP and Valeport locations. Deep layer current was directed to the east, i.e., onshore, when southerly flow occurred in the upper layer and to the west or southwest, when the current to the northeast prevailed. These are signs of the layered structure of the coastal upwelling and downwelling.

The most frequent current direction in the upper layer (11 m depth) was $40^{\circ}$ at the ADCP location. To estimate the relationship between the low-frequency (10-day low-passed) current component and wind, we calculated the correlation between the $40^{\circ}$ current velocity component $\left(\mathrm{c}_{40}\right)$ in the upper layer and wind speed from different directions with different time lags. The best correlation $\left(r^{2}=0.65, p<10^{-100}\right.$, $\mathrm{n}=4473$ ) was found with the wind from the south, specifically towards $10^{\circ}\left(\mathrm{w}_{10}\right)$, applying a 3-day time lag. This, on the one hand, corresponds to Ekman's theory, however, on the other hand, the 3-day delay is rather long. Probably it can be explained by the mixed effect of wind on the surface currents. The momentum flux created by wind impacts the current field fast. The correlation without delay is relatively high $\left(\mathrm{r}^{2}=0.55, \mathrm{p}<10^{-100}, \mathrm{n}=4473\right)$ as well. The flow resulting from the sea level gradient and due to the inclination of isopycnal surfaces are also a consequence of wind but develop slower.

Time series of $\mathrm{c}_{40}$ reveal negative values from mid-April until the end of June (Fig. 3e). Before midMarch and in July-August, the $\mathrm{c}_{40}$ was mostly positive. The main course of $\mathrm{w}_{10}$ and $\mathrm{c}_{40}$ coincided well, but discrepancies occurred in the details. For instance, negative $\mathrm{c}_{40}$ occurred when $\mathrm{w}_{10}$ was positive in the ADCP location in the last third of March and first half of May. The mean values of $\mathrm{w}_{10}$ and $\mathrm{c}_{40}$ during the measurements were $0.6 \mathrm{~m} \mathrm{~s}^{-1}$ and $3.2 \mathrm{~cm} \mathrm{~s}^{-1}$, respectively. Considering the linear relation between the two variables, the $1979-2020$ mean $\mathrm{w}_{10}=1.1 \mathrm{~m} \mathrm{~s}^{-1}$ corresponds to $\mathrm{c}_{40}=4.2 \mathrm{~cm} \mathrm{~s}^{-1}$.

The most frequent current direction was $350^{\circ}$ at the Valeport location. The discrepancy between the dominant flow direction at the ADCP and Valeport locations is related to the topographic features (Fig. 
analyze the measured and simulated meridional current components at $11 \mathrm{~m}$ depth at the ADCP location, $\mathrm{V}_{\mathrm{ADCP}}$ and $\mathrm{V}_{\mathrm{GETM}}$. We also calculated the geostrophic component $\mathrm{V}_{\mathrm{GEO}}$-SL-GETM of the current velocity from the simulated sea level gradient, relative geostrophic meridional current component ( $\mathrm{V}_{\text {GEO-DENS-GETM }}$ ) at $11 \mathrm{~m}$ depth based on simulated temperature and salinity data in the section and same for the glider temperature and salinity data ( $\left.\mathrm{V}_{\mathrm{GEO} \text {-DENS-glider }}\right)$. We also calculated mean Ekman current $u$ - and $v$-components in the depth range 0-10 $\mathrm{m} \mathrm{U}_{\text {Ekman }}$ and $\mathrm{V}_{\text {Ekman }}$, respectively. All parameters are 36-h low-passed filtered.

Overall, the simulated $\mathrm{V}_{\text {GETM }}$ reasonably well follows the temporal changes in measured $\mathrm{V}_{\mathrm{ADCP}}$ (Fig. 5). $V_{\text {GETM }}$ tends to have smaller values than $V_{A D C P}$, which means that the meridional component of simulated velocity is biased southward. Sometimes, e.g., in June and August, the discrepancies are considerable. Geostrophic current $\mathrm{V}_{\text {GEO-DENS-GETM }}$ was very small, and $\mathrm{V}_{\text {GEO-DENS-glider was practically }}$ zero in March (Fig. 5b) as the water column was mixed down to the reference depth of the geostrophic current calculation. Since the end of March, overall temporal developments in the meridional current ( $\mathrm{V}_{\mathrm{ADCP}}$ and $\mathrm{V}_{\mathrm{GETM}}$ ) and its geostrophic components ( $\left.\mathrm{V}_{\text {GEO-DENS-GETM }}\right)$, $\left(\mathrm{V}_{\text {GEO-SL-GETM }}\right)$ and $\mathrm{V}_{\text {GEO-DENS- }}$ glider) in August match quite well (Fig. 5a and b). This can be related to the multiple effects of wind. South-westerly wind resulted in the Ekman current towards the eastern coast of the Northern Baltic Proper. This caused, first, a sea level gradient across the basin (higher near the coast), which induced barotropic current to the north. Secondly, it evoked downwelling along the coast and resulted in a vertical gradient of the geostrophic current. Such events were detected at the beginning of April and July, when strong southwesterly winds blew (Fig. 4) and caused Ekman current towards the coast (Fig. 5c). Northerly or northeasterly winds caused opposite effects. Sea level was lower near the coast compared to offshore and thermocline was located at shallower depths near the coast. Thus, the flow was directed to the south in the surface layer. Such events occurred in late March and mid-August. Most of the major events of the positive $\mathrm{V}_{\mathrm{ADCP}}$ and $\mathrm{V}_{\mathrm{GETM}}$ were associated with the positive $u$ component of the Ekman current (cf. Fig. 5a and c), i.e., flow towards the shore, not along the shore. Thus, the wind-driven strong coastal current to the north is not induced by the direct momentum flux created by wind stress but rather is the result of wind-driven sea level gradient and depression of the pycnoclines at the coast, which resulted in vertically sheared geostrophic current.

Next, we consider the relationship between the vertical maxima of the current shear and the vertical location of pycnoclines - seasonal thermocline and halocline. Seasonal thermocline began to develop from the beginning of May (Fig. 6a). The temporal course of salinity at $67 \mathrm{~m}$ depth (Fig. 6b) and depth of halocline center $(\mathrm{CH})$ (Fig. 6d) showed that halocline was mostly located deeper than the deepest ADCP bin. At the end of March, the halocline center reached $55 \mathrm{~m}$ depth (Fig. 6d) and high current shear values were observed below $45 \mathrm{~m}$ depth (Fig. 6c). Shallower halocline was related to the northerly wind event (Fig. 4), which caused offshore Ekman transport in the upper layer and compensating onshore flow in the deep layer (Fig. 3). Such events of high current shear in the deep layer also occurred at the end of April to early May, from the end of May to mid-June and in midAugust (Fig. 6c) when the halocline center was shallower, and salinity increased at $67 \mathrm{~m}$ depth. Note that the depth of the halocline center and shear maxima were vertically shifted, halocline center was deeper. This can be explained by the vertical range of the halocline. The upper boundary of the halocline is shallower than the center of the halocline. Thus, the shear maxima were rather linked to the upper boundary of the halocline.

Stronger and more extensive shear maxima in the upper part of the water column were observed since late April (Fig. 6c). It appeared days before thermal stratification developed. One could see that SST (sea surface temperature) and temperature at $67 \mathrm{~m}$ depth coincided until the end of April. The occurrence of earlier shear maxima could be explained by the formation of the stratification in the 
upper layer caused by the transport of fresher surface water to the area due to northerly wind forcing. Shear maxima became stronger in the second half of May when thermal stratification developed. Strong downwelling and likely also vertical mixing occurred in July as a result of a strong southwesterly wind impulse with the duration of more than a week (Fig. 4). This can be seen as a drop in SST from 21 to $15^{\circ} \mathrm{C}$ and occasional high temperature recordings in the deep layer (Fig. 6a). The latter indicates that the upper layer water arrived at the $67 \mathrm{~m}$ deep measurement spot. This event is well reflected in the time series of current shear. Deepening of the shear maxima down to 50-55 $\mathrm{m}$ depth (Fig. 6c) occurred together with thermocline deepening, as the near-bottom temperature recordings suggest. Relaxation of the downwelling occurred in mid-July, and another downwelling developed at the end of July. The linkage between the thermocline and shear maxima was well seen in August when glider observations were available. The thermocline and shear maxima reached down to $40 \mathrm{~m}$ depth in the beginning and the end of the month, while they were located at $20 \mathrm{~m}$ depth in the middle of the month (Fig. 6a and c). The vertical movements of the halocline (Fig. 6d) and thermocline and linked shear maxima were synchronized. As thermocline, the halocline had its position also shallower in midAugust and deeper before and after. Note that downwelling was initiated by strong southerly, southwesterly or westerly winds and all events were seen as a SST decrease, likely due to vertical mixing, decrease in salinity at $67 \mathrm{~m}$ depth and deepening of the thermocline and halocline and related shear maxima. Relaxation of downwelling occurred when northerly winds or calmer periods prevailed and appeared as an increase in SST and upward movement of both pycnoclines.

Thus, we can conclude that the vertical structure of currents was strongly linked to the varying depths of pycnoclines, which were sensitive to wind forcing.

349 Table 1. Statistics of the 1-h average ADCP current data from 28 February to 2 September 2020.

\begin{tabular}{|c|c|c|c|c|c|}
\hline Depth (m) & $\begin{array}{c}\text { Mean speed } \\
\left(\mathrm{cm} \mathrm{s}^{-1}\right)\end{array}$ & $\begin{array}{c}\text { Mean } u \\
\left(\mathrm{~cm} \mathrm{~s}^{-1}\right)\end{array}$ & $\begin{array}{c}\text { Mean } v \\
\left(\mathrm{~cm} \mathrm{~s}^{-1}\right)\end{array}$ & $\begin{array}{c}\text { Maximum } \\
\text { speed }\left(\mathrm{cm} \mathrm{s}^{-1}\right)\end{array}$ & $\begin{array}{c}\text { Persistency } \\
(\%)\end{array}$ \\
\hline 10.8 & 11.3 & 3.8 & 1.1 & 48 & 35.1 \\
\hline 20.8 & 10.2 & 4 & 1.7 & 44 & 42.3 \\
\hline 30.8 & 9.5 & 3.7 & 1.4 & 38 & 41.7 \\
\hline 40.8 & 9 & 3.4 & 1.1 & 37 & 40.1 \\
\hline 50.8 & 8.8 & 2.9 & 0.8 & 35 & 34.5 \\
\hline 60.8 & 8.3 & 2.7 & 0.7 & 36 & 34 \\
\hline 66.8 & 7 & 1.9 & 1.2 & 34 & 32.7 \\
\hline
\end{tabular}


a) u-component $\left[\mathrm{cm} \mathrm{s}^{-1}\right]$

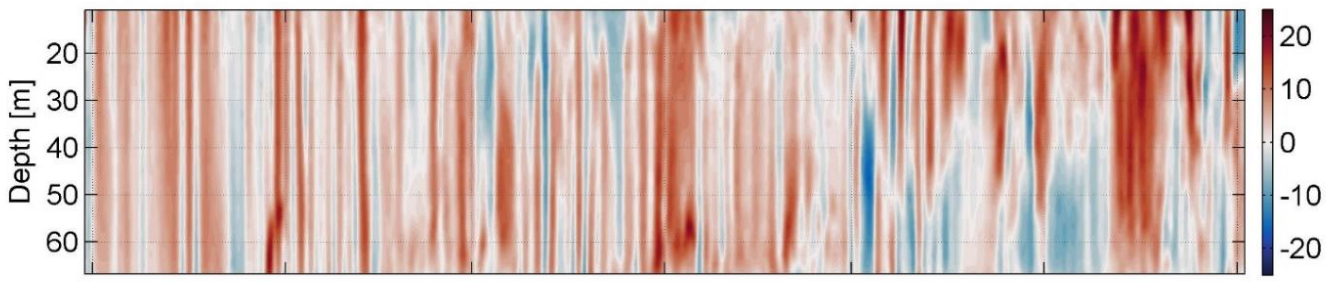

b) v-component $\left[\mathrm{cm} \mathrm{s}^{-1}\right]$
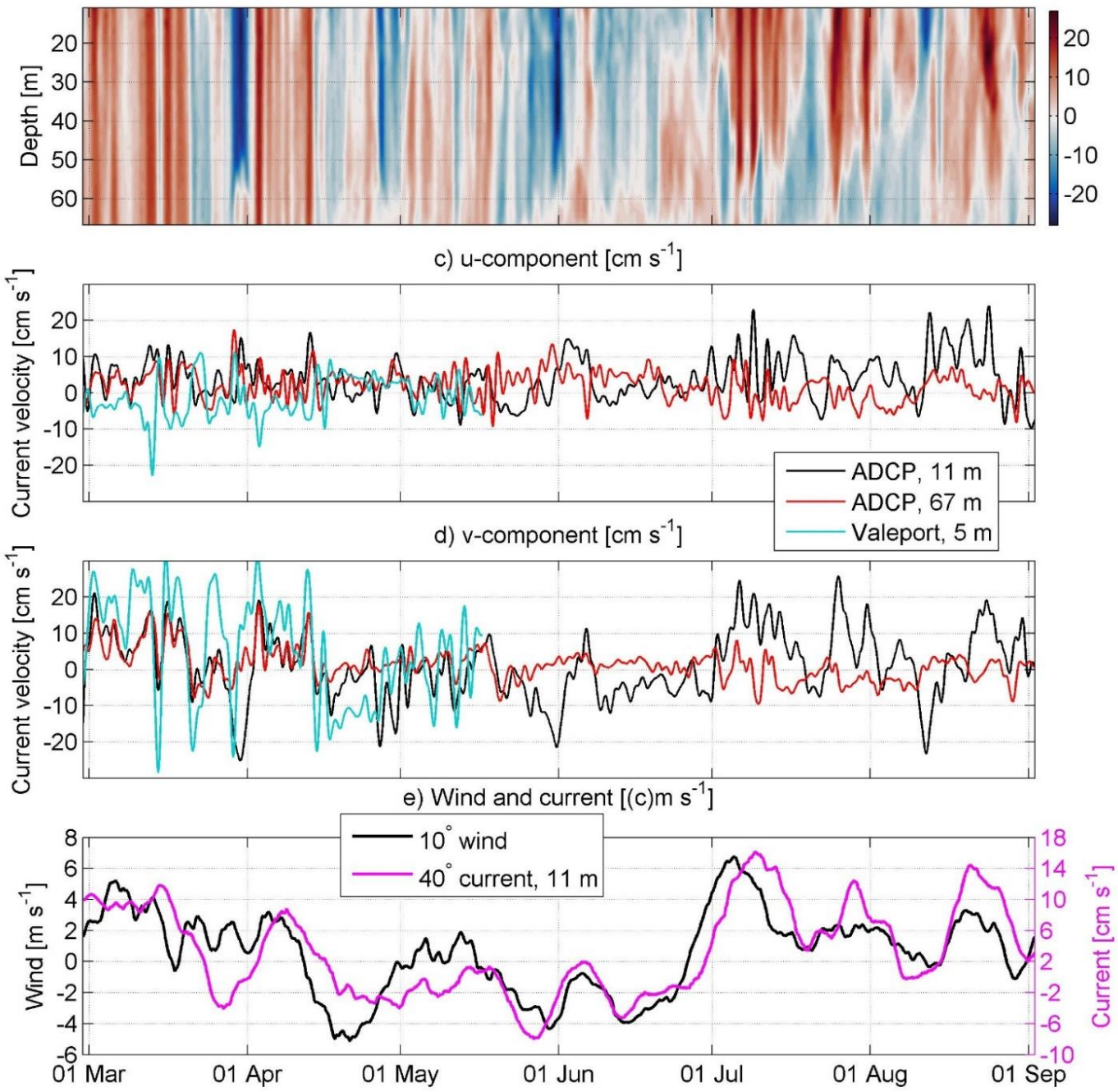

Figure 3. Temporal course of the low-pass filtered ( $36 \mathrm{~h})$ current velocity $u$-component (positive eastward, a and c) and v-component (positive northward, b and d) in the water column (a, b); and in the upper (11 $\mathrm{m}$ depth) and deep layer (67 m depth, c, d) in the ADCP and Valeport locations in 2020 (Fig. 1). Low-pass filtered (10 days) wind $10^{\circ}$-component and current $40^{\circ}$-component at $10 \mathrm{~m}$ depth in the ADCP location (e). 

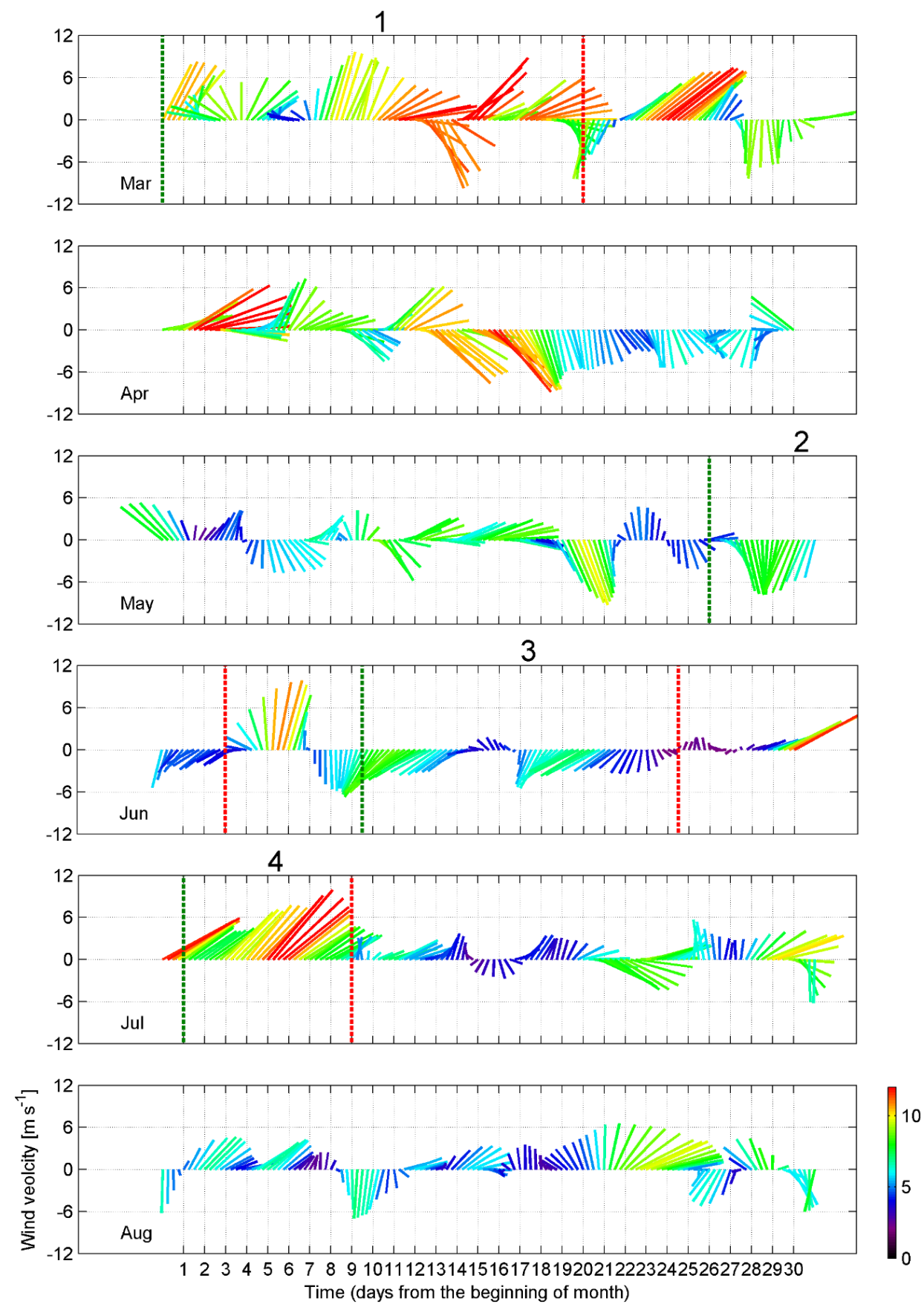

Figure 4. Time series of the 10-m level ERA5 wind data from 1 March to 31 August 2020. Four selected periods are shown: 1) prevailing southwesterly wind, 1-21 March; 2 and 3) prevailing northerly wind, 27 May -4 June and 10-25 June; 4) prevailing southwesterly wind, 2 July-10 July. The green dotted line marks the beginning and red dashed line marks the end of the period. Wind data were smoothed with a 36-h filter. Color scale shows wind speed in $\mathrm{m} \mathrm{s}^{-1}$. 

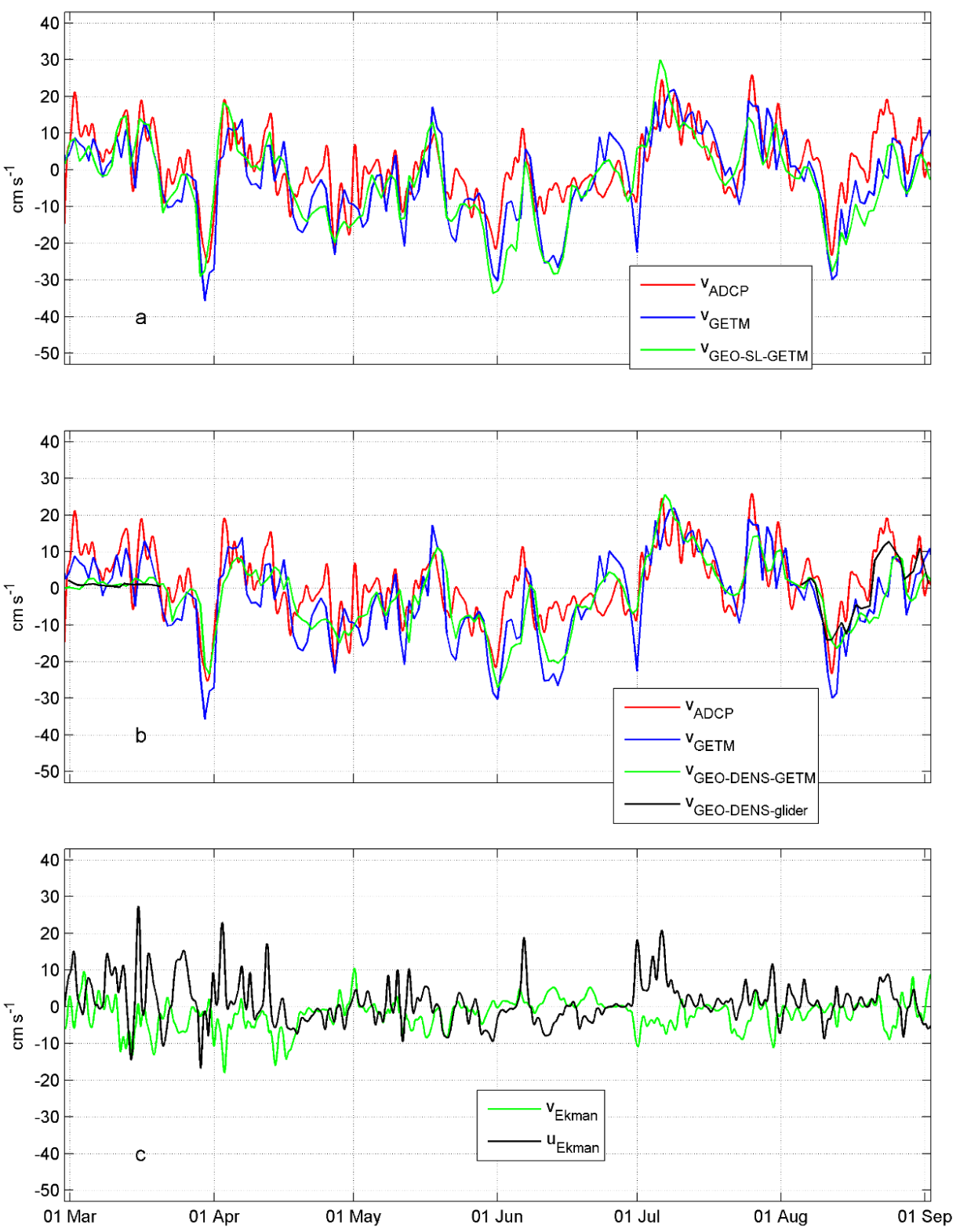

Figure 5. Temporal courses of (a, b panel) current velocity $v$-component measured by $\mathrm{ADCP}\left(\mathrm{V}_{\mathrm{ADCP}}\right)$, simulated $v$-component $\left(\mathrm{V}_{\mathrm{GETM}}\right)$, estimated from the GETM sea level data $\left(\mathrm{V}_{\text {GEO-SL-GETM }}\right)$, estimated from temperature and salinity data collected by glider $\left(\mathrm{V}_{\mathrm{GEO}} \mathrm{DENS}\right.$-glider $)$, estimated from temperature and salinity data simulated by GETM at $11 \mathrm{~m}$ depth ( $\left.\mathrm{V}_{\text {GEO-DENS-GETM }}\right)$. Mean Ekman current $u$-component and $v$-component ( $\mathrm{U}_{\text {Ekman }}$ and $\left.\mathrm{V}_{\text {Ekman }}\right)$ in the depth range 0-11 m (c). Time-series are shown from March to September 2020 at the ADCP location (see Fig. 1). 
a) Temperature $\left[{ }^{\circ} \mathrm{C}\right]$

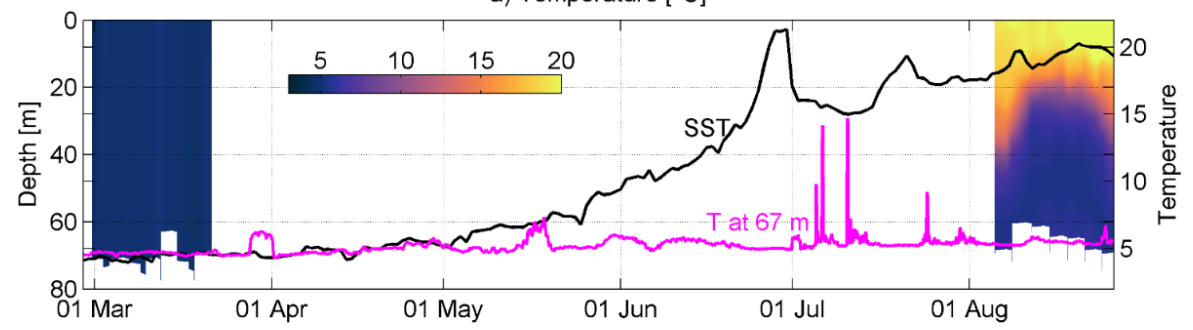

b) Salinity $\left[\mathrm{g} \mathrm{kg}^{-1}\right]$
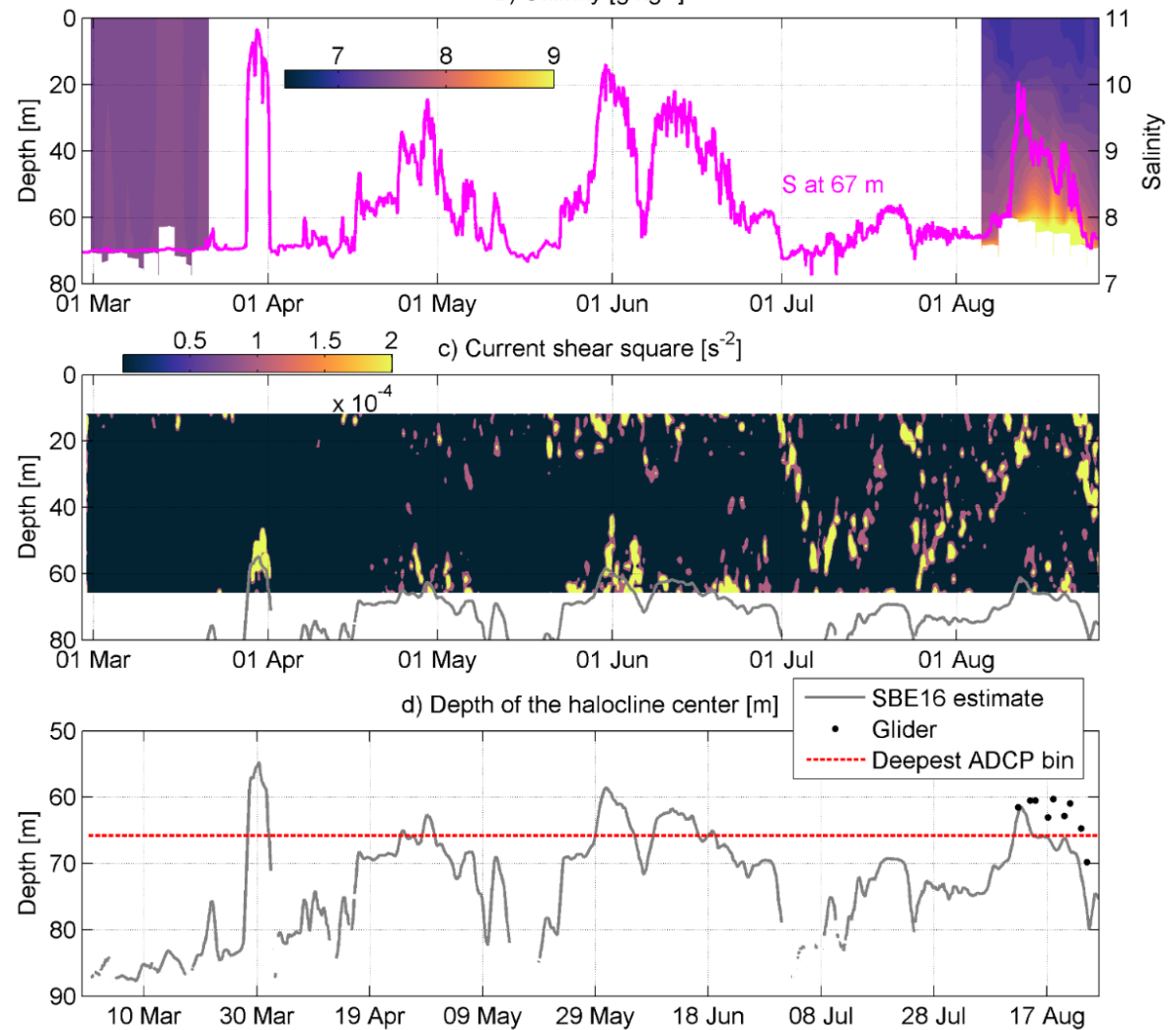

Figure 6. Temporal courses of temperature, salinity, current shear squared and halocline depth in the ADCP location from March to September 2020 (see Fig. 1b and c). (a) Temporal course of sea surface temperature (SST) and temperature at $67 \mathrm{~m}$ depth; temporal course of the vertical distribution of mean temperature in March and August calculated from glider data. (b) Temporal course of salinity at $67 \mathrm{~m}$ depth; temporal course of the vertical distribution of mean salinity in March and August calculated from glider data. Mean temperature and salinity profiles were calculated for each glider passing within the $3.7 \mathrm{~km}$ zonal window around the ADCP location. (c) Temporal course of the vertical distribution of current shear squared and depth of the halocline center (grey line). (d) Depth of halocline center, calculated from SBE16 data and in August from glider data. Depth of deepest ADCP bin is also shown (red dotted line). 


\subsection{Quasi-permanent circulation patterns}

In the previous chapter, we demonstrated the importance of wind forcing and stratification for the currents. Next, we describe the current structure during the quasi-steady forcing periods. We have selected four periods of 8-21 days duration with relatively stable forcing (see Fig. 4) to analyze the mean measured and simulated flow structure in the ADCP and Valeport location (Fig. 7) and along the zonal section (Fig. 8). Likewise, we investigated the lateral simulated flow structures in the three forcing cases in three layers: upper layer $(5 \mathrm{~m})$, intermediate layer $(40 \mathrm{~m})$ and deep layer (110 $\mathrm{m})$ (Figs. 9-11).

The persistency of the currents was very high in all selected periods (Table 2). Only during the fourth period, the persistency was lower than $50 \%$ below the seasonal thermocline. Particularly high persistency (82-94\%) occurred in the first and second periods. Thus, currents during the quasi-steady forcing have much higher persistency than overall of the time series (see Table 1).

Barotropic flow to the northeast prevailed throughout the water column at the ADCP location in the first period (1-21 March) when south-westerly wind prevailed (Fig. 7a and b). Even stronger mean current to the north-northwest was registered at $5 \mathrm{~m}$ depth at the Valeport location (Fig. $3 \mathrm{c}$ and d). Latter indicates the boundary effect near the Saaremaa Island. The current was directed along the coast. Mean flow was to the south in the upper layer during the second period (27 May-4 June) when northerly wind prevailed to the southeast below the thermocline and to the east below the halocline (Fig. 7e and f). In general, a similar current pattern occurred in the third period (10-25 June) when north-westerly wind prevailed (Fig. $7 \mathrm{i}$ and $\mathrm{j}$ ). Due to relatively strong south-westerly wind forcing in the fourth period (2-10 July), flow to the northeast prevailed in the upper layer and to westerly directions below the thermocline (Fig. $7 \mathrm{~m}$ and $\mathrm{n}$ ).

In conclusion, a pattern typical for the downwelling event - current to the northeast along the boundary and towards the shore in the upper layer and seaward current to the southeast in the deep layer occurred during southwesterly wind domination (Fig. $7 \mathrm{f}$ and j). The flow was to the south in the upper layer along the coast and onshore (east) in the deep layer, which is typical for the upwelling cell in the case of northerly winds (Fig. 7n). These vertical patterns of the current velocity were also well captured by the numerical model (Fig. $7 \mathrm{~g}, \mathrm{k}$ and o), although the magnitude of the mean simulated velocity occasionally deviated from the measured values. Likewise, the stronger mean measured current near the boundary at the Valeport location, was well reproduced by the model (Fig. 7b and c). Geostrophic velocities had a quite similar vertical structure compared to the measured velocities in all periods (Fig. 7 , third and fourth columns). Thus, currents were generally in geostrophic balance during the quasisteady periods. The transition from one state to another has likely an ageostrophic nature, as wind is the main driver for the change.

Next, we analyze the vertical (Fig. 8) and horizontal (Fig. 9-11) structure of the mean meridional component of currents in the section along the latitude of the ADCP location (Fig. 1) and in the Eastern Gotland Basin using simulated current data. The current data are averaged within the same time windows with relatively stable wind forcing as analyzed above.

The structure of the meridional component of currents in the section is characterized by high spatial and temporal variability (Fig. 8). The unidirectional flow prevailed in most of the section down to the halocline or even deeper in the case of no thermal stratification and southwesterly winds (first period) (Fig. 8a). The northward current along the eastern boundary with a cross-coast extent of $10 \mathrm{~km}$ was especially strong. This strong boundary current was also registered by the Valeport (Fig. 3d). The strong maxima of the northward flow can be found between $20.5^{\circ}-21.0^{\circ} \mathrm{E}, 18.6^{\circ}-19.3^{\circ} \mathrm{E}$ and around 

E. Horizontal flow structure in the Eastern Gotland Basin consisted of the two stronger current zones above the halocline, northward current along the eastern boundary and southward current in the middle part (Fig. 9a and b). The two zones were connected with several cyclonic cells. The northward flow below the halocline (Fig. 9c) coincided with the flow in the upper layer in the Eastern Gotland Basin area but forced to the westward trajectory by bathymetry in the northern area.

The flow patterns were very similar in the following two periods (second and third) of prevailing northerly winds and the presence of thermocline. In both cases, the zonal scale of the southward flow around the ADCP location was $10-15 \mathrm{~km}$ (Fig. 8b and c). The flow did not extend to the eastern boundary, a narrow northward flow with a width of 5-10 km occurred along the coastal slope. The width of the southward flow near the western boundary of the section was about $30 \mathrm{~km}$. In between, several circulation cells with zonal scales of $20-60 \mathrm{~km}$ can be distinguished in the cross-section (Fig. 10a). The horizontal structure of the flow below the thermocline in the Eastern Gotland Basin revealed a strong southward current in the eastern part of the area in the second period (Fig. 10b). The current swirled, split into two branches and re-merged back to one in several locations. The southward flow below the thermocline coincided with the offshore branch in the upper layer in the central area of the basin (Fig. 10a and b). Sub-halocline flow revealed strongest northward current and strongest cyclonic cell in the Eastern Gotland basin among the selected periods (Fig. 10c).

The flow pattern in the case of strong southwesterlies dominance (fourth period) under stratified conditions revealed a strong northward current along both boundaries of the section (Fig. 8d). In between, the strong southward flow occurred in the surface layer. Similarly, to the northerly wind prevailing, complicated three-layer structure with variable horizontal patterns in the zonal scale of 20 $60 \mathrm{~km}$ occurred. Flow to the southeast prevailed in the upper layer, except in the eastern boundary zone, where a strong northward downwelling related flow occurred (Fig. 11a), as also was observed in our ADCP mooring data (Fig. 7n). A strong current occurred also in the Irbe Strait towards the Gulf of Riga. Downwelling related flow along the eastern coast was also observed at $40 \mathrm{~m}$ depth (Fig. 11b). In the deep layer below the halocline, northward current along the eastern bottom slope and cyclonic cells in the Eastern Gotland Basin were observed (Fig. 11c).

Due to seasonality in forcing, variations in the circulation in this time scale can be expected. The boundary current in the eastern coast occurs year-round but is the strongest in winter. This is related to the wind regime: southwesterly winds prevail more in winter but are less frequent in spring and summer. The seasonal signal can be found in the whole section (Fig. 12). Well defined large cyclonic gyres in the Eastern Gotland Basin can be found in winter, while in spring and summer, the mean current structure is characterized by the smaller zonal scale features and weaker flow. However, it is noteworthy that the mean flow is to the north along the eastern coastal slope in all seasons.

\subsection{Sub-halocline current}

Cyclonic gyre was present below the halocline in the Eastern Gotland Basin in all selected periods (Figs. 9-11). The flow in this cyclonic system was especially strong along the eastern slope of the Eastern Gotland Basin. The northern branch of this circulation system is connected to the clearly distinguishable northward current. The position and magnitude of the current varied under different conditions. The current was stronger and meandered to west at the shallower area between Gotland and 
Basin and the northward flowing current towards the Northern Deep, the Argo float trajectory and the mean current field were plotted in the same time frame (Fig. 13a). The general features in the simulated mean currents and the Argo float trajectory agreed well. The Argo float first completed two circles (smaller and larger) in the Eastern Gotland Basin and then headed to the north. The float arrived and was recovered in the shallower area between the Fårö and Nothern Deep. This sill is an important location for the deep layer water renewal in the Northern Baltic Proper (see bathymetry in Fig. 14), as this is the only remarkable passage to the north below $100 \mathrm{~m}$ depth. The sill is located slightly south of the selected section along the latitude of the ADCP deployment.

The flow to the north over the still was concentrated in a narrow cell with a zonal scale of 5-6 km (Fig. 15a). The flow was especially strong when northerly winds prevailed, e.g., in the second period from 27 May to 4 June (Fig. 15b). The 2010-2020 mean density field sloped downward in the left (west) of the flow, typical for a gravity current (Fig. 15a-b). The meridional current velocity $\left(\mathrm{C}_{\mathrm{T}}\right)$ in the trench was mostly positive (northward) and in the range of $10-20 \mathrm{~cm} \mathrm{~s}^{-1}$ during the study period in 2020 (Fig. $15 \mathrm{c})$. The $\mathrm{C}_{\mathrm{T}}$ was reversed in the first half of July, which coincided with the strong southwesterly wind impulse (Fig. 4). The time series of $C_{T}$ for 2010-2020 (Fig. 15d) revealed many reversal events, but the long-term mean meridional velocity was $10 \mathrm{~cm} \mathrm{~s}^{-1}$ to the north. Reversals were most frequent in November-December when the monthly mean southward $C_{T}$ was $6-7 \mathrm{~cm} \mathrm{~s}^{-1}$ and rarer in March-May when monthly averages were in the range of $12-14 \mathrm{~cm} \mathrm{~s}^{-1}$. Thus, the deep layer water renewal in the Northern Baltic Proper is most active in the spring period and more restricted in late autumn-early winter. The best correlation $\left(\mathrm{r}^{2}=0.25, \mathrm{p}<10^{-100}, \mathrm{n}=3838\right)$ between 10 -day low-passed current velocity at the sill and wind was found with the wind from ENE $\left(70^{\circ}\right)$ with a delay of 6 days. This is another confirmation that prevailing southwesterly winds slow down or reverse the $\mathrm{C}_{\mathrm{T}}$ and prevent deep water renewal in the Northern Baltic Proper.

Table 2. Persistency (\%) of the currents at the selected depths during the selected periods: 1 March to 21 March (1); 27 May to 4 June (2); 10 June to 25 June (3); 2 July to 10 July (4) in 2020.

\begin{tabular}{|r|r|r|r|r|}
\hline $\begin{array}{l}\text { Period/ } \\
\text { depth }(\mathrm{m})\end{array}$ & 1 & 2 & 3 & 4 \\
\hline 10.8 & 84.8 & 82 & 75.8 & 83.1 \\
\hline 20.8 & 88.8 & 92.3 & 76.9 & 78.9 \\
\hline 30.8 & 88.8 & 94 & 66.2 & 54.8 \\
\hline 40.8 & 88.6 & 92.5 & 62.1 & 41.3 \\
\hline 50.8 & 89.3 & 89.9 & 61.4 & 24 \\
\hline 60.8 & 87.7 & 91.1 & 70.1 & 27.5 \\
\hline 66.8 & 87.2 & 86.1 & 64.1 & 4.7 \\
\hline
\end{tabular}

502 
01-Mar-2020 - 21-Mar-2020
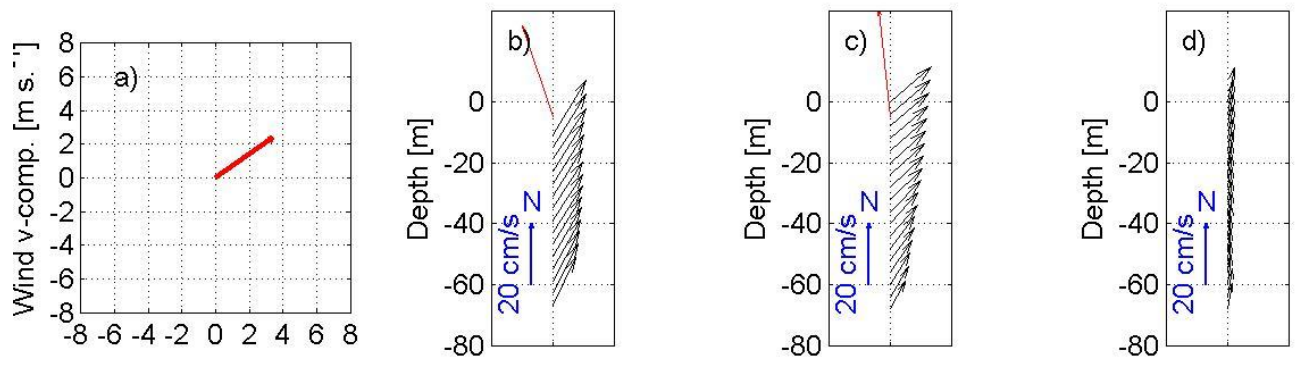

27-May-2020 - 04-Jun-2020
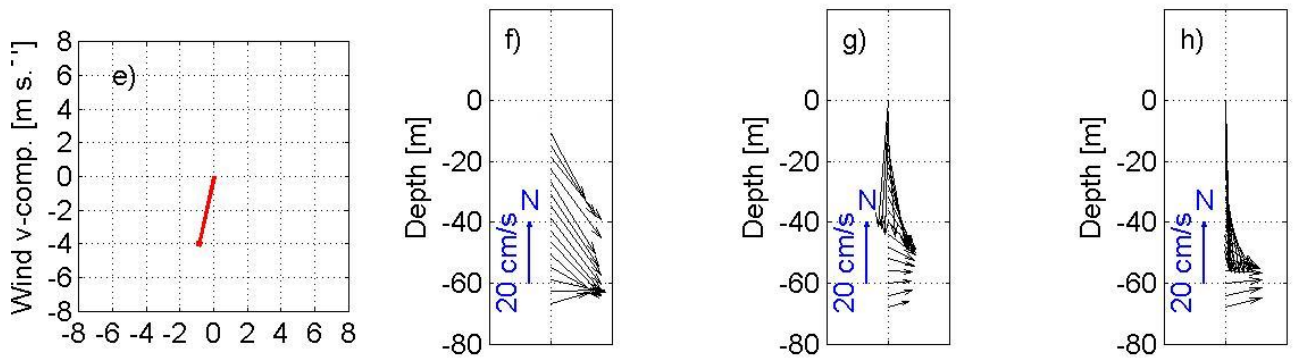

10-Jun-2020 - 25-Jun-2020
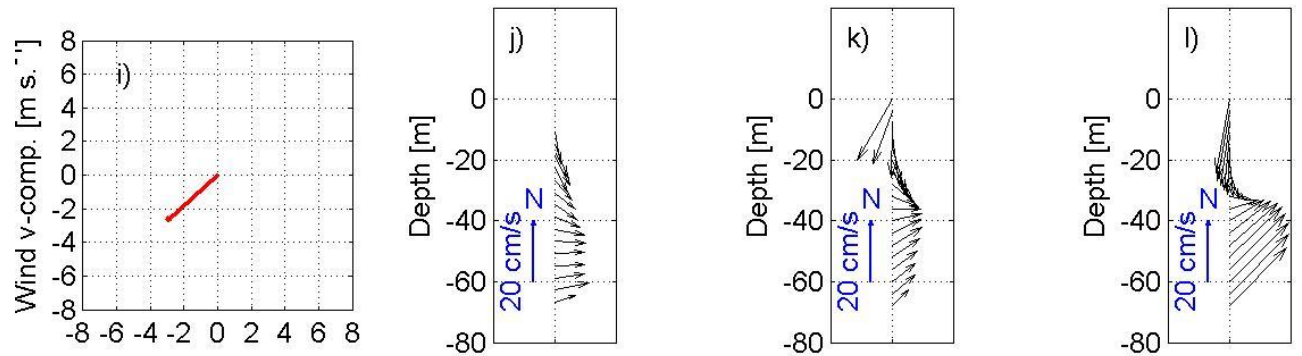

02-Jul-2020 - 10-Jul-2020
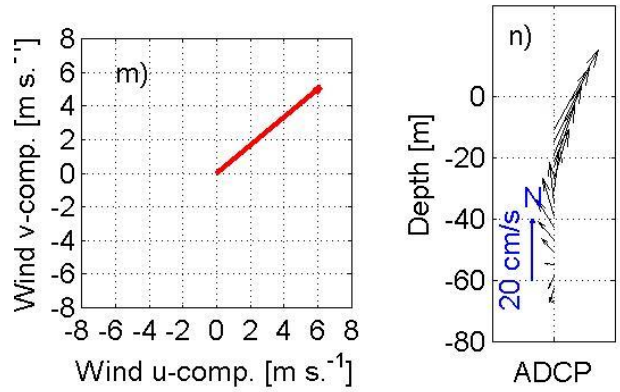

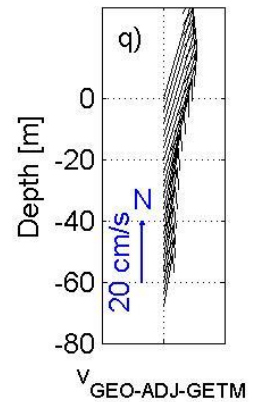

Figure 7. The mean resultant wind vectors (a, e, i, m), mean profiles of current velocity vectors calculated from ADCP data (black arrows, b, f, j, n), mean current velocity vector based on Valeport data at $5 \mathrm{~m}$ depth (b, red arrow), mean simulated current velocity vectors at the ADCP location (c, g, k, o) and at the Valeport location (c, red arrow) are shown for selected periods (Fig. 4). On the right panels, mean adjusted geostrophic velocity vectors $\mathrm{V}_{\mathrm{GEO}-\mathrm{ADJ}-\mathrm{GETM}}(\mathrm{d}, \mathrm{h}, \mathrm{i}, \mathrm{q})$ are shown. 

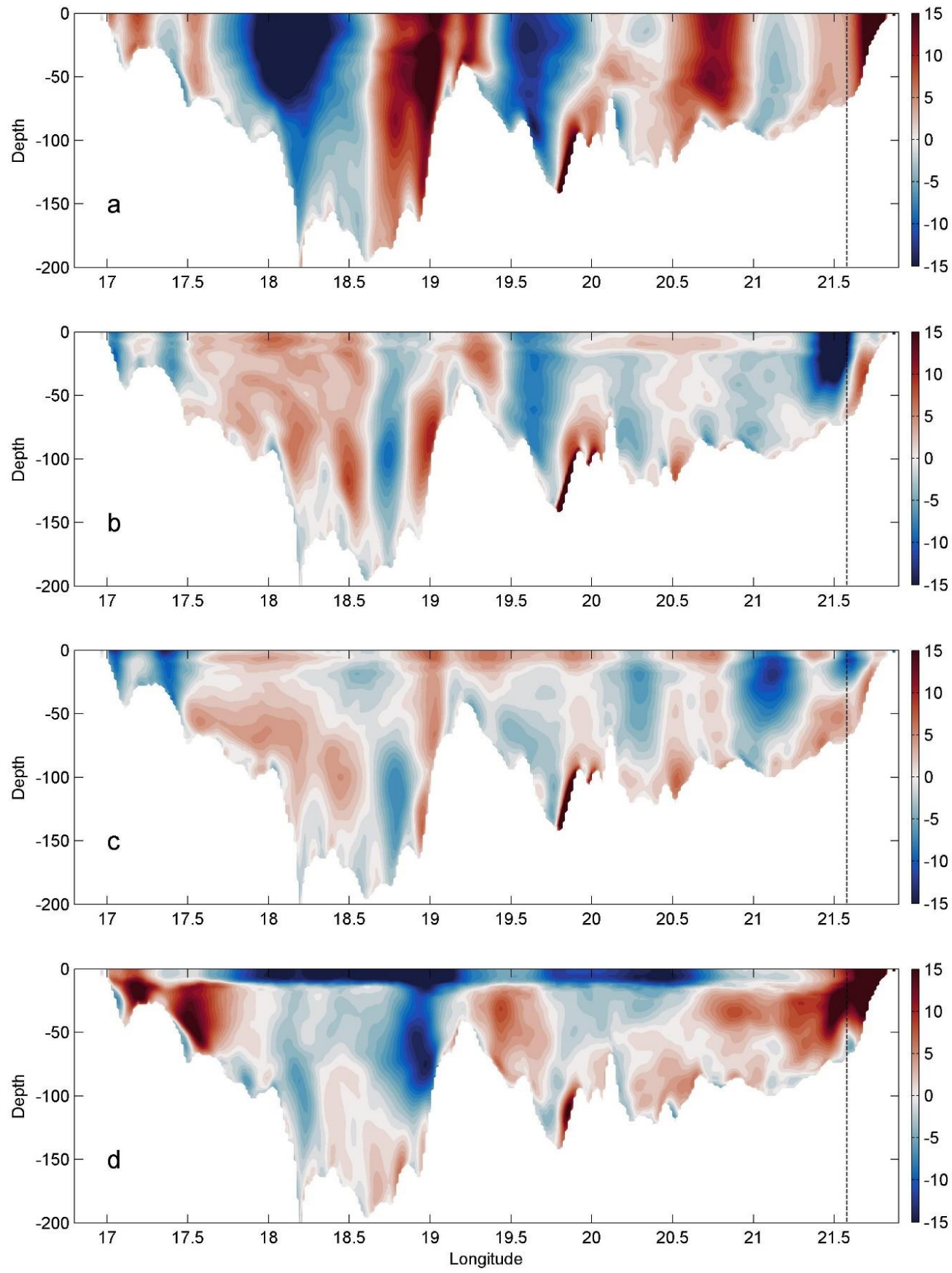

Figure 8. Vertical distribution of mean meridional current velocities for four selected periods (see Fig. 4) along the ADCP deployment latitude (Fig. 1b). Color scale displays meridional velocity (positive northward) in $\mathrm{cm} \mathrm{s}$

$513 \quad$ 1. Vertical dotted lines show the ADCP location. 
https://doi.org/10.5194/os-2021-123

Preprint. Discussion started: 4 January 2022

(c) Author(s) 2022. CC BY 4.0 License.
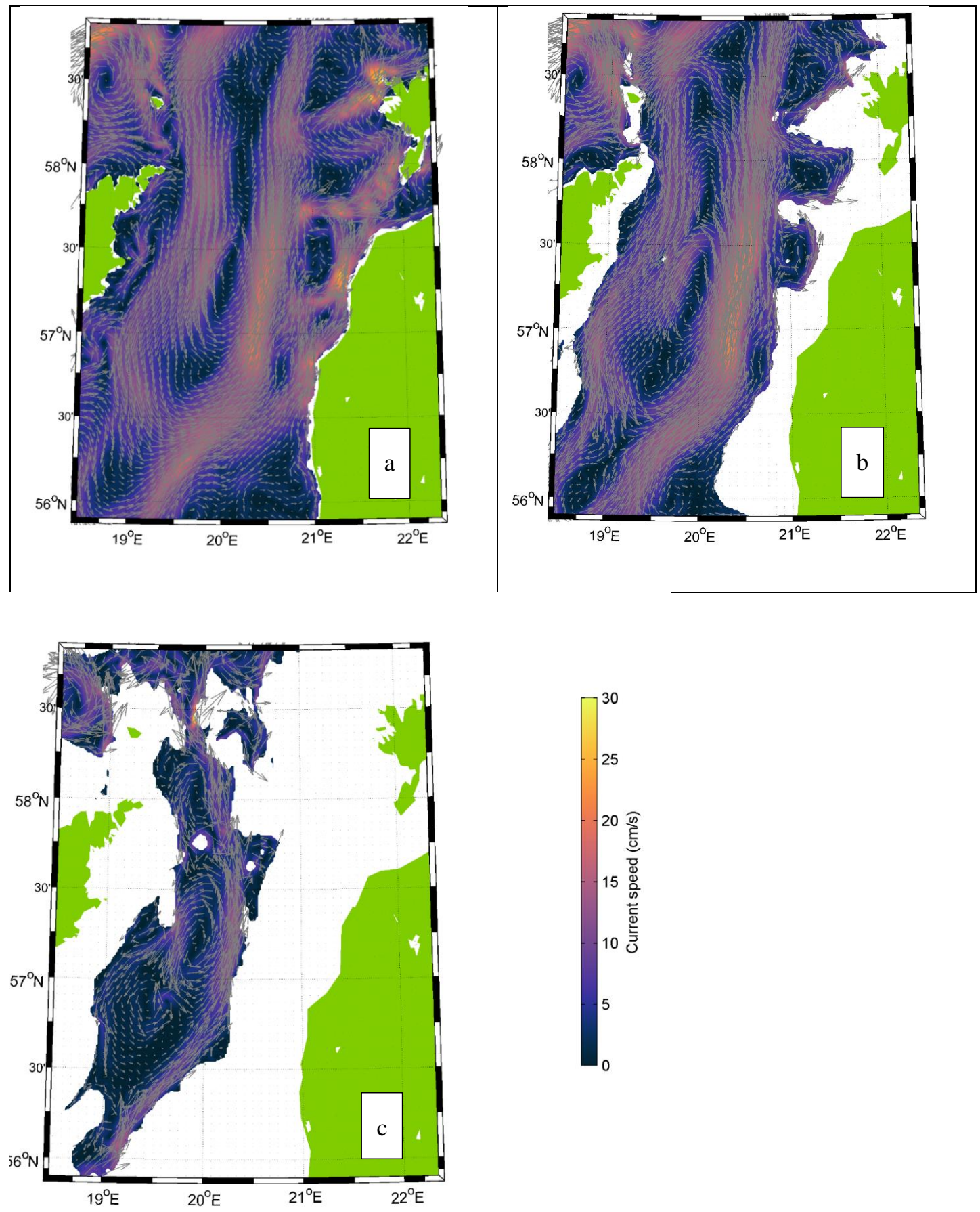

Figure 9. Mean currents in the case of prevailing south-westerly winds from 1 March to 21 March 2020, without thermocline at $5 \mathrm{~m}$ depth (a), $40 \mathrm{~m}$ depth (b) and $110 \mathrm{~m}$ depth (c). Color scale shows current speed in $\mathrm{cm} \mathrm{s}^{-1}$. 

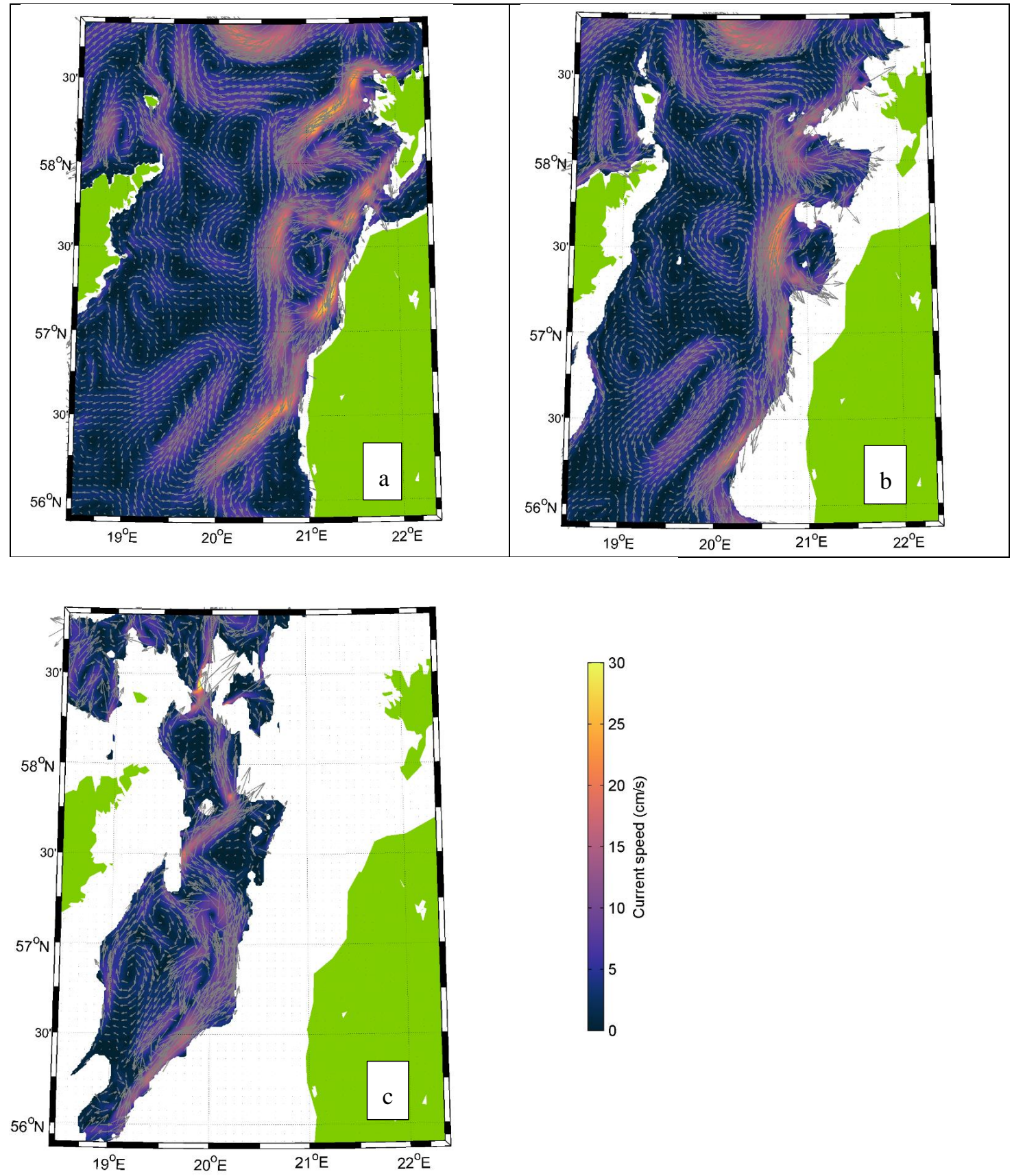

Figure 10. Mean currents in the case of prevailing northerly winds from 27 May to 4 June 2020, with thermocline at $5 \mathrm{~m}$ depth (a), $40 \mathrm{~m}$ depth (b) and $110 \mathrm{~m}$ depth (c). Color scale shows current speed in $\mathrm{cm} \mathrm{s}^{-1}$. 

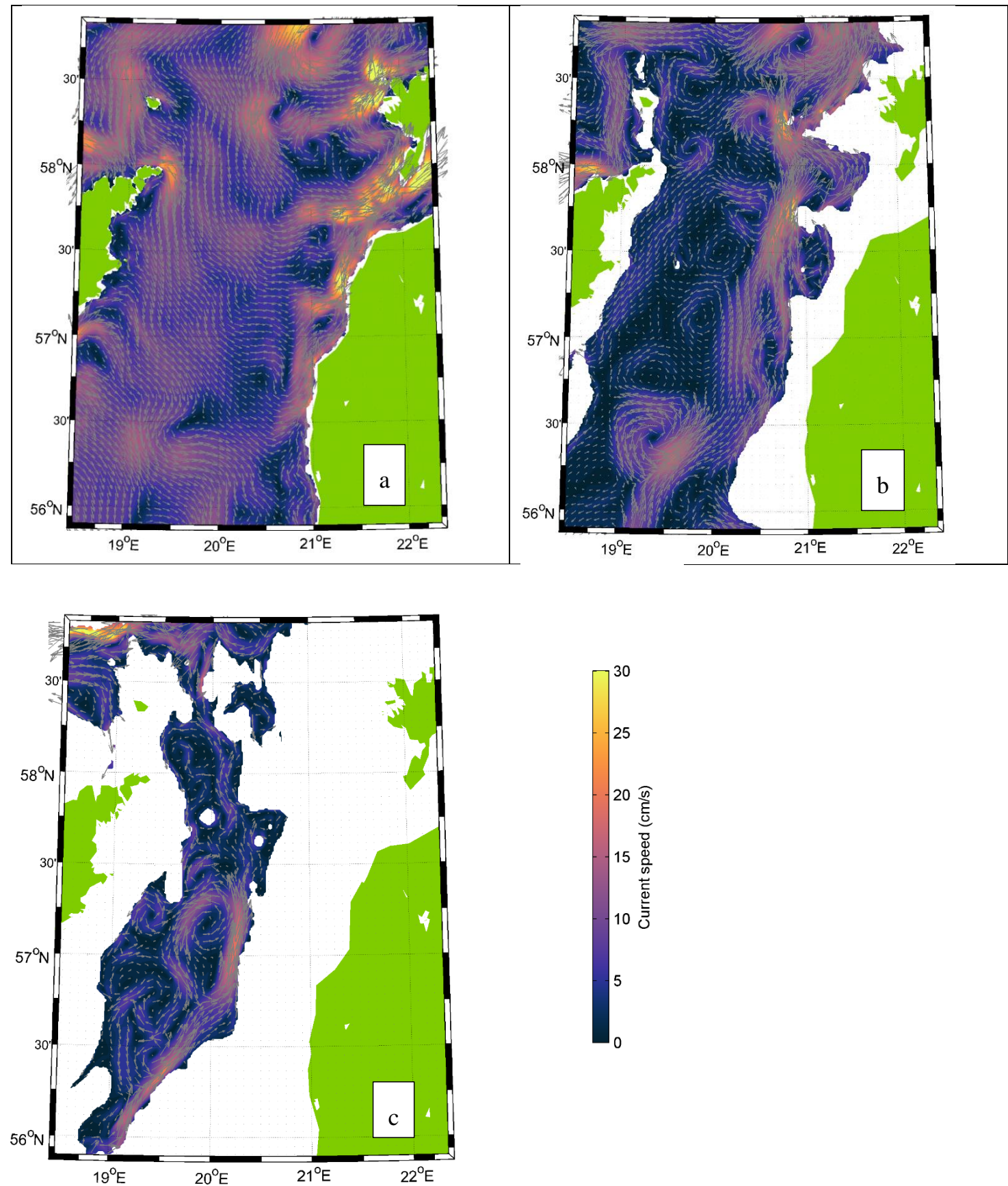

Figure 11. Mean currents in the case of prevailing south-westerly winds from 2 July to 7 July 2020, with thermocline at $5 \mathrm{~m}$ depth (a), $40 \mathrm{~m}$ depth (b) and $110 \mathrm{~m}$ depth (c). Color scale shows current speed in $\mathrm{cm} \mathrm{s}^{-1}$. 

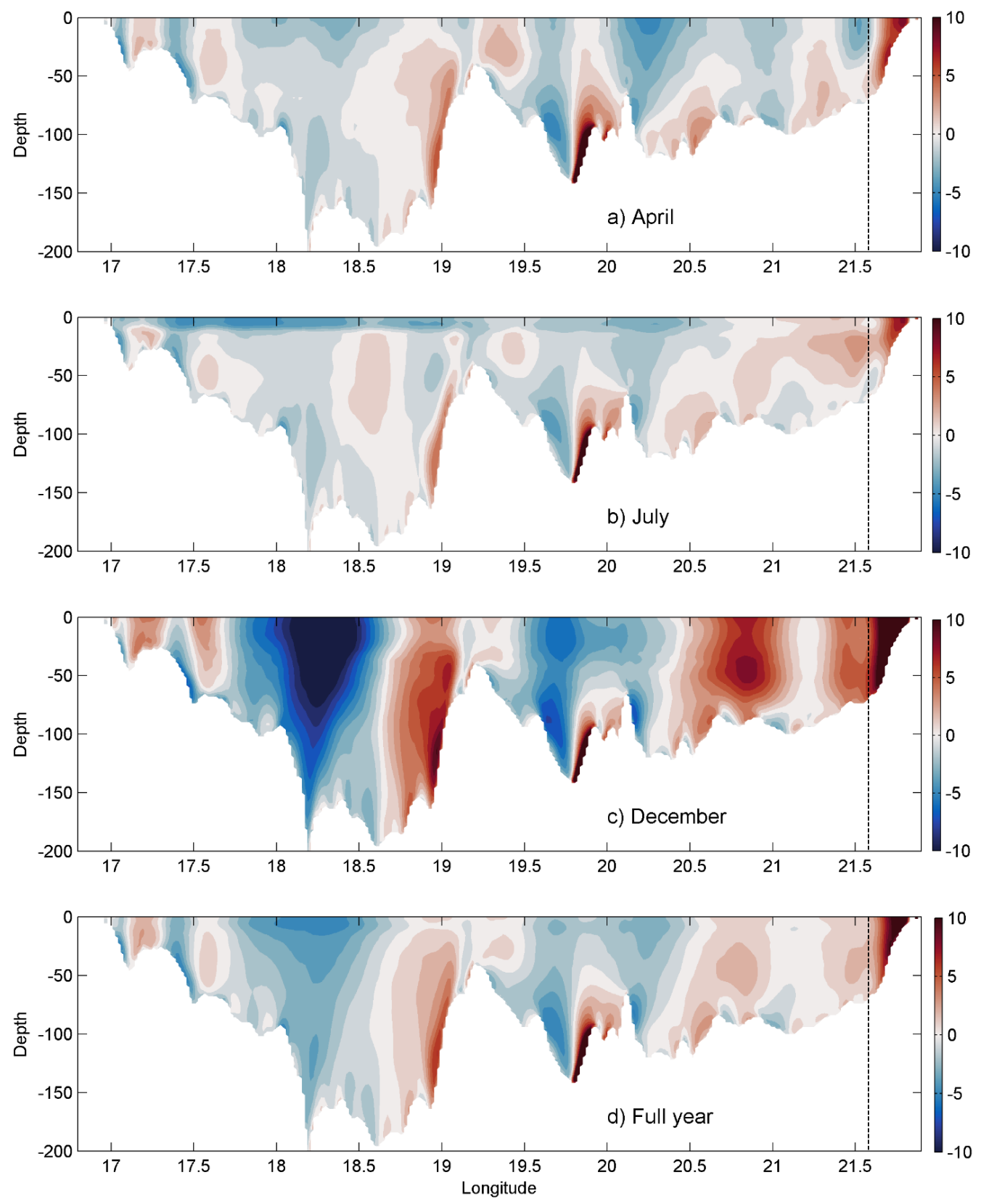

Figure 12. Vertical distribution of monthly mean (April, July and December) and annual mean meridional velocities (positive northward) along the zonal section at ADCP latitude based on simulation data from September 2010 to August 2020. Color scale shows meridional velocity in $\mathrm{cm} \mathrm{s}^{-1}$. Vertical dotted lines show the ADCP location. 


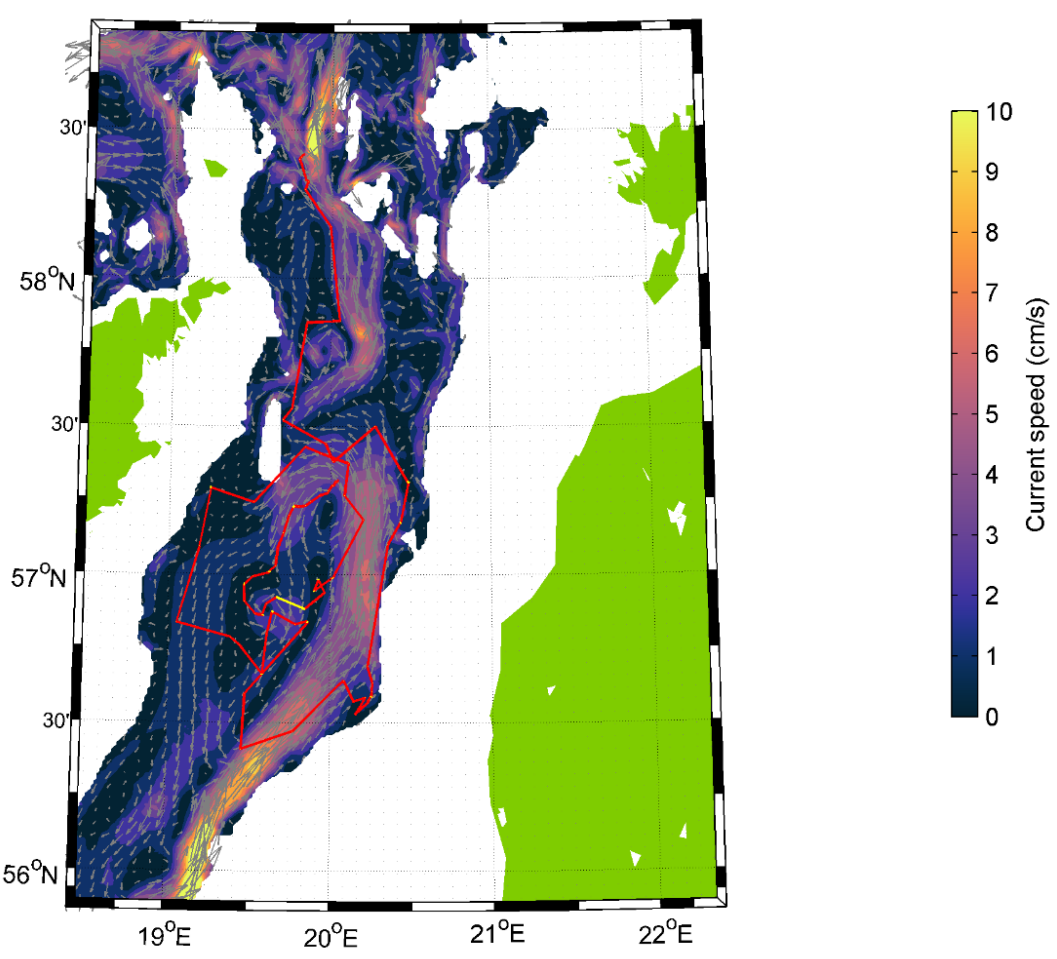

Figure 13. Mean current field between 105-135 $\mathrm{m}$ depth based on simulation data and ARGO float trajectory during the period 15 August 2013-15 August 2014 in the deep layer (105-135 m, shown in red). Only one longer period occurred, when the float drifted on the surface (shown in white). Color scale shows current speed in $\mathrm{cm}$ 


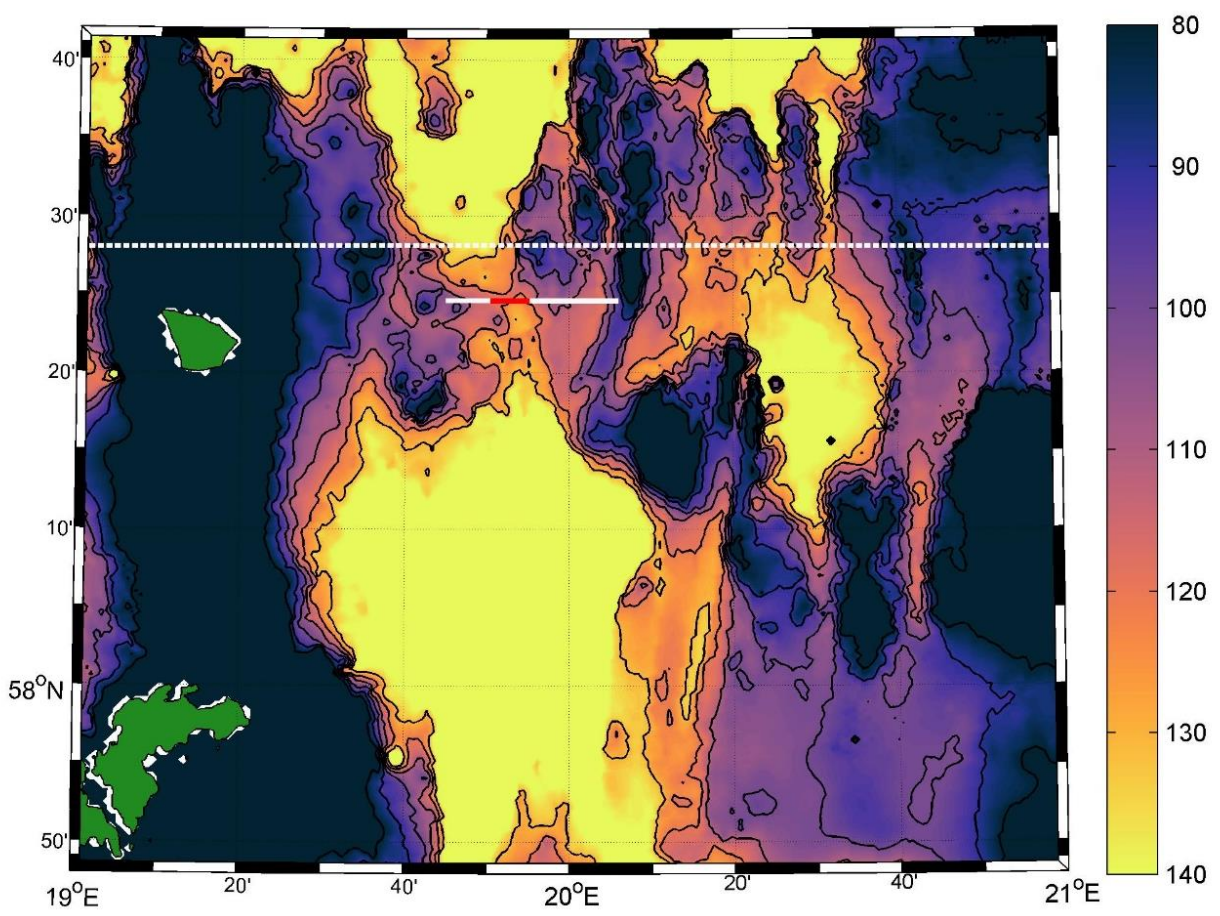

Figure 14. Bathymetry between Farö Deep and Northern Deep (see Fig. 1b). Color scale shows the depth in meters. White dashed line marks the section along the ADCP deployment latitude (Fig. 1b). White line marks the section in Fig. 15a, and red line indicates time-series calculation range for Fig. 15b-c. 

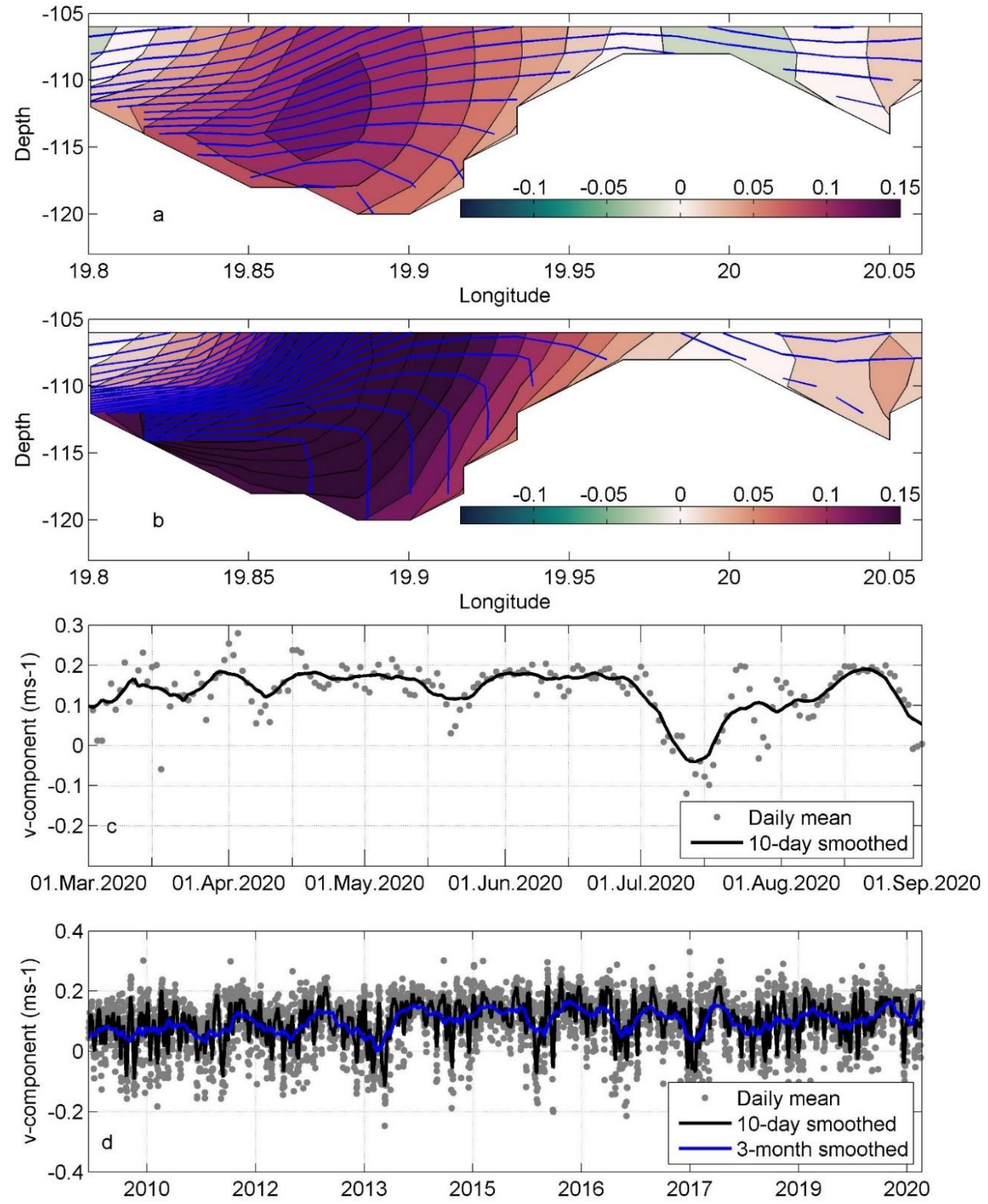

Figure 15. (a) mean simulated meridional current component $v$ and density isolines at section below $105 \mathrm{~m}$ depth (the section location is shown as red line in Fig. 14) in 2010-2020, (b) mean meridional current component $v$ and density isolines at section below $105 \mathrm{~m}$ depth from 27 May to 4 June 2020 during a northerly wind impulse. In color scale contours with step of $2 \mathrm{~cm} \mathrm{~s}^{-1}$ show current $v$-component ( $\mathrm{m} \mathrm{s}^{-1}$, positive northward) and blue lines show density isolines with a step of $0.05 \mathrm{~kg} \mathrm{~m}^{-3}$. (c) time-series of $v$ component below $105 \mathrm{~m}$ at the sill. Dots marks the daily mean and bold line 10-day smoothed $v$-component from March to September. (d) timeseries of $v$ component below $105 \mathrm{~m}$ at the sill. Dots marks the daily mean, bold black line 10-day smoothed and bold blue line 3-month smoothed $v$-component in the period 2010-2020. 


\section{Discussion}

Moorings carrying ADCP and single-point current meter, and underwater glider surveys were applied, together with numerical modelling to investigate circulation in the Baltic Proper.

Strong linkage between the vertical location of the current shear maxima and the two pycnoclines was observed. The same finding was reported in the Gulf of Finland (Suhhova et al., 2018). The current shear maxima in the Gulf of Finland were related to the along-gulf estuarine circulation and its alterations. In the present case, the shear maxima were related to the currents along the basin axis and the coastal downwelling and upwelling circulation structures. The separation of the cross-shelf flow by a pycnocline has been documented in several other coastal systems (Davis, 2010; Gilcoto et al., 2017; Villacieros-Robineau et al., 2013).

Boundary current in the upper layer along the eastern coast was observed. The current was well correlated with the wind. The wind regime in the area is the combination of the global circulation and specific direction-dependent boundary-layer effects, which results in domination of winds along the axis of the Baltic Proper (Soomere \& Keevallik, 2001). Along-axis wind causes the Ekman current (Ekman, 1905) to the right from wind direction in the upper layer, i.e., a flow across the basin axis. The resulting convergence (divergence) in the case of southwesterly (northerly) winds at the eastern coast causes across-axis sea level gradient and the upper pycnocline inclination, which in turn cause horizontal pressure gradient, and results in a geostrophic flow to the north (south) in the upper layer. Boundary currents forced by the pressure gradient caused by wind-driven divergence/convergence are common in coastal systems (Berden et al., 2020; Longdill et al., 2008; H. Wu et al., 2013). The geostrophic current velocity is well agreed with the total current velocity profiles. Thus, the current along the boundary was generally in the geostrophic balance, but across-shore ageostrophic flow created preconditions for this geostrophic coastal current.

Circulation rapidly reacted to the wind forcing. Persistency of the current for 6 months was rather low $(30-40 \%)$ due to variability in the wind forcing. The estimated persistency from long-term numerical simulations data in the same area above the halocline was 70-80\% in 1981-2004 (Meier, 2007) but around 30-40\% in the upper layer in 1958-2007 (Jędrasik \& Kowalewski, 2019). However, the quasisteady circulation patterns detected under different wind and stratification conditions were highpersistent, mostly $>75 \%$.

The mean cyclonic circulation in the upper layer of the Baltic Proper has been reported by many modeling studies (Hinrichsen et al., 2018; Jedrasik et al., 2008; Jędrasik \& Kowalewski, 2019; Meier, 2007; Placke et al., 2018). However, the magnitude of the long-term mean circulation patterns had a considerably lower magnitude than the quasi-steady circulation structures presented in this study. Likewise, the current direction of quasi-steady patterns varied and differed considerably from the longterm mean. The circulation structures in this timescale also differ from the long-term mean because of seasonal and inter-annual variations in the forcing. The cyclonic circulation and the eastern boundary current towards the north in the upper layer is stronger in autumn and winter, as noted by previous simulations (Jędrasik \& Kowalewski, 2019), when strong southwesterly winds are more frequent (Soomere \& Keevallik, 2001). Quasi-steady circulation patterns were characterized by complicated lateral vortices with the zonal scale of $20-60 \mathrm{~km}$. The richness of vortical structures has been suggested by several numerical modelling studies (Dargahi, 2019; Zhurbas et al., 2021). In-situ measurements 
are needed to verify the existence of the vortices and to characterize their effect on the physical and biogeochemical fields in more detail.

Two quasi-permanent circulation features were detected in the deep layer. Cyclonic gyre was present below the halocline in the Eastern Gotland Basin, with the strongest flow along the eastern slope, which has been documented by in-situ measurements earlier (Hagen \& Feistel, 2004; Hagen \& Feistel, 2007). The northern branch of the Eastern Gotland Basin current is connected to the quasi-steady northwardflowing current towards narrow Fårö sill between the Fårö and Nothern Deep. The width of the current was mostly $10-30 \mathrm{~km}$, but only $5 \mathrm{~km}$ at the sill. The mean northward component of the current was 10 $\mathrm{cm} \mathrm{s}^{-1}$, which can be explained by the mean density structure (Fig. 15a) and is typical for the gravity current in a channel (Zhurbas et al., 2012). This current is an important deeper limb of the Baltic haline conveyor belt (Döös et al., 2004). The current was stronger in the case of northerly winds and weaker during southwesterly wind prevailing. This is typical behavior of the estuarine circulation: up-estuary wind causes weakening or reversal of the deep layer current and down-estuary wind intensification of the estuarine current (Geyer \& MacCready, 2014) as observed in the Gulf of Finland (Liblik et al., 2013; Lilover et al., 2017; Suhhova et al., 2018) and several other estuaries (e.g. Giddings \& MacCready, 2017; Scully, 2016). In the case of northerly wind, the vertical and horizontal density gradient in the Fårö sill was much stronger (Fig. 15b) than the mean gradient in 2010-2020 (Fig. 15a) according to the simulation. Note that on the right-hand flank, the isopycnals are vertical (Fig. 15b). A similar structure of the gravity current has been measured by acoustic profiling in the Western Baltic (Umlauf et al., 2009). The current to the north and potentially the deep layer water renewal in the Northern Baltic Proper is more intense in March-May when southwesterly winds are less frequent, and the current is weakest in November-December. If the water that overflows the Fårö sill is dense enough, it occupies the Northern Deep bottom layers, and the old, oxygen-depleted bottom water is lifted and advected to the Gulf of Finland, as observed during high Major Baltic Inflow activity (Liblik et al., 2018). If the overflow has a lower density compared to the deep layer waters in the Northern Deep, it does not dive to the bottom but stays as a buoyant layer.

The most favorable wind for the up-estuary deep layer advection in the Gulf of Finland is from the northeast (Elken et al., 2003). Thus, northerly winds support deep water renewal and strengthening of the stratification all the way from the Gotland Deep to the Gulf of Finland. The deep layer currents are quite well covered by observations in the Gulf of Finland (Lilover et al., 2017; Rasmus et al., 2015; Suhhova et al., 2018). However, observations are lacking from the Gotland Deep to the entrance of the Gulf of Finland. The only in-situ record about the feature between Gotland and Northern Deep is the Argo float track. The Argo trajectory supported our suggestion about the existence of the sub-halocline current to the north. Our simulations suggested that the strength and position of the current did depend on the wind forcing. Observations and simulation results at the channel-like topographic constriction, Slupsk Furrow, in the southern Baltic have shown that the meandering of the gravity current is strongly affected by the bottom topography and wind-forcing (Zhurbas et al., 2012). ADCP measurements are needed to understand the behavior of the sub-halocline current better.

Overall, simulated currents quite well agree with the ADCP measurements in the upper layer. However, the meridional component of the simulated current $\left(\mathrm{V}_{\mathrm{GETM}}\right)$ was biased (Fig. 5a). The mean $\mathrm{V}_{\mathrm{ADCP}}$ was $1.1 \mathrm{~cm} \mathrm{~s}^{-1}$, but the mean $V_{\text {GETM }}$ was $-3.2 \mathrm{~cm} \mathrm{~s}^{-1}$ at $10 \mathrm{~m}$ depth during the study period. Such bias could not be found in the deep layer. Flow to the north was often weaker compared to measurements $\left(\mathrm{V}_{\mathrm{ADCP}}\right)$, and flow to the south was stronger than observed by the ADCP in the upper layer. A similar tendency 641 can be found in a comparison of the ADCP measurements and simulation results in the Gulf of Finland 
(Suhhova et al., 2015). Near the right-hand side coast (looking up-estuary, i.e., to the east in the Gulf of Finland), the down-estuary flow was stronger and more frequent in the simulation compared to the measurements (see their Fig. 2). Interestingly, a similar bias was detected in the deep layer at the eastern flank of the Gotland Deep at $204 \mathrm{~m}$ depth (Placke et al., 2018). Four different models considerably underestimated (Placke et al., 2018) the mean flow to the north derived from observations (Hagen \& Feistel, 2004). The first possible explanation for the bias could be the smaller width of the boundary current. Indeed, the mean flow towards north in 2010-2020 was stronger in the east from the ADCP location (Fig. 12). The second possible source for the discrepancy could be related to the performance of simulation of ageostrophic or geostrophic flow. We will discuss this further in the next section.

Quite large discrepancies between the simulation and the measurements occurred in June. In the first half of the month, simulation was biased to the south, but in the second half, a bias to the north can be seen (Fig. 5a). In both cases, the geostrophic current seems to play an important role in the discrepancy.

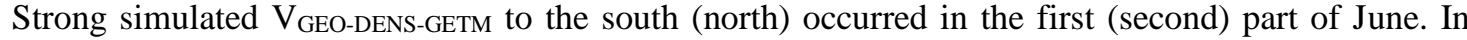
August, the simulation did not capture the strongest flow event to the north on 21-24 August (Fig. 5a).

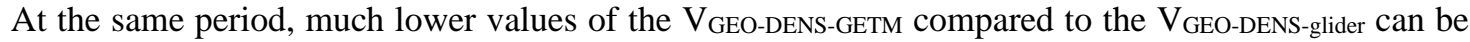
seen. These signs suggest, first, that the isopycnals in the model react to the forcing more rapidly than in the sea. Secondly, there is a bias in the across/slope seasonal thermocline inclination. Likely, the thermocline is tilted more towards the surface near the coast in the model than in the sea. We next evaluate the measured (by glider) and simulated temperature, salinity and geostrophic velocity fields on 11-12 August and on 22-23 August.

Surface layer geostrophic velocity in the simulation agrees well with the estimates from the glider data on 11-12 August (Fig. 16a-b). Though, the glider observations reveal sharper thermocline inclination than the simulation. Discrepancies in the temperature, density, and geostrophic current fields on 22 23 August are much larger (Fig. 16c-d). Glider observations revealed the thermocline depressed down near the coast, which is typical for a downwelling. The inclination in the thermocline caused strong geostrophic flow to the north in the location of ADCP (Fig. 16c). Homogenous mixed layer reached down to $22 \mathrm{~m}$ depth at the easternmost end of the section. Such an inclination, well defined homogenous layer and geostrophic current to the north at the ADCP location was not revealed by the simulation (Fig. 16c). Thus, we can conclude that the bias in the boundary current simulation could be related to the inaccuracy of reproducing the temperature and salinity fields and the resulting geostrophic component of currents. We are not going into further details of this problem here, as it is out of the focus of the present work. However, conclusions of the simulation studies that have focused on the long-term mean current fields in the upper layer, but did not validate simulations with direct current observations, should be taken carefully, as the magnitude of the long-term residual current is very small compared to the magnitude of the currents during the quasi-steady states. We suggest a dedicated study involving numerous current profiling records should be conducted to track down the causes of the discrepancies between observations and simulations. 

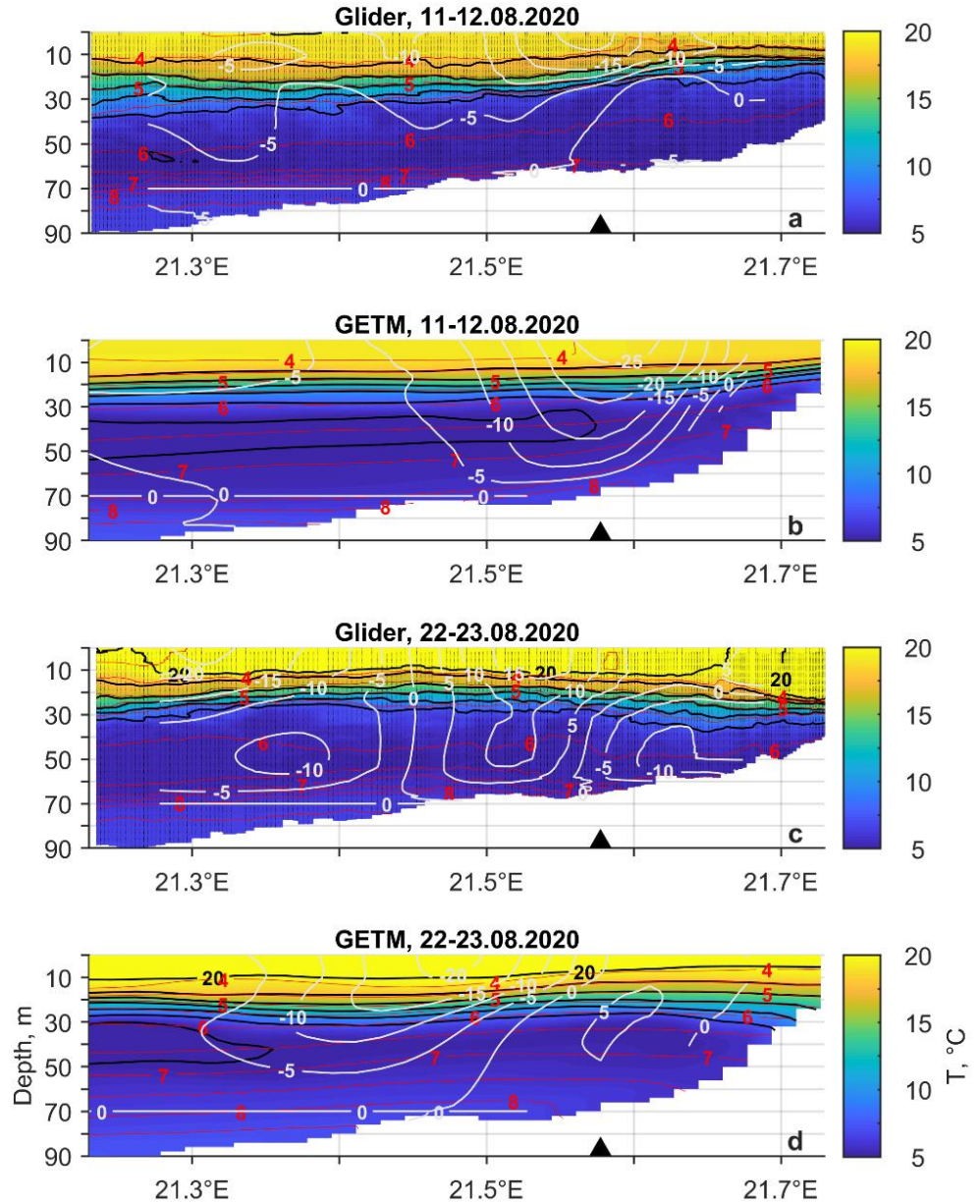

680

681 Figure 16. Temperature (color contours), density isolines (red lines), relative geostrophic current (white lines) 682 based on glider observations and GETM simulation on 11-12 August and 22-23 August 2020.

683

684

685 


\section{Conclusions}

687

A strong link between the existence and location of the two pycnoclines and the current structure was observed. Boundary current was observed in the upper layer along the eastern coast of the Baltic Proper. The current was mainly in geostrophic balance, but across-shore Ekman transport created preconditions for the geostrophic coastal current. The boundary current rapidly reacted to the changes in the wind forcing that is reflected in a relatively low persistency of currents (30-40\%) in the whole water column during the 6-month measurement period. However, the quasi-steady circulation patterns formed under the certain wind and stratification conditions were high-persistent (mostly >80\%) and generally in the geostrophic balance.

The sub-halocline, quasi-steady northward (towards Fårö sill) gravity current with a width of 10-30 $\mathrm{km}$ was detected by the simulation. The finding was supported by the Argo float displacement data. This important deeper limb of the Baltic Sea haline conveyor belt is stronger in the case of northerly winds and weaker during south-westerlies. More detailed studies of the dynamics and water properties of this current are essential to understand the renewal process of deep layer waters in the Northern Baltic Proper and in the Gulf of Finland.

Generally, the structure of boundary current was well reproduced by the GETM. However, the meridional component of the simulated current was biased southward. Further investigations of the current regimes in various locations during the periods of quasi-steady forcing could help to reveal the causes of the discrepancy.

Code availability. Scripts to analyze the results are available upon request. Please contact Taavi Liblik.

Autor contributions. TL led the analyses of the data and writing of the paper with contributions from GV, JL, UL, KS and MJL. TL was responsible for the measurements and data processing, and GV for the modelling activities. KS processed the glider data.

Competing interests. The authors declare that they have no conflict of interests.

Acknowledgements. We would like to thank our colleagues and research vessels Salme crew for all the support in measurements and operations at sea. The computing time from high-performance computing center at Tallinn University of Technology and University of Tartu are gratefully acknowledged. GETM community at Leibniz Institute of Baltic Sea Reasearch are gratefully acknowledged for maintaining and developing the code.

Financial support. This work was supported by the Estonian Research Council grant PRG602. Collection of the data was financially supported by the European Regional Development Fund within National Programme for Addressing Socio-Economic Challenges through R\&D (RITA). Infrastructure assets used in the current study are part of the JERICO infrastructure and supported by the JERICOS3 project under the European Union's Horizon 2020 research and innovation programme with grant number 871153. 


\section{References}

Berden, G., Charo, M., Möller, O. O., \& Piola, A. R. (2020). Circulation and Hydrography in the Western South Atlantic Shelf and Export to the Deep Adjacent Ocean: $30^{\circ} \mathrm{S}$ to $40^{\circ} \mathrm{S}$. Journal of Geophysical Research: Oceans, 125(10), e2020JC016500. https://doi.org/10.1029/2020JC016500

Book, J., Perkins, H., Signell, R., \& Wimbush, M. (2007). The Adriatic Circulation Experiment winter 2002/2003 mooring data report: a case study in ADCP data processing. In U.S. Naval Res. Lab. Stennis Space Center.

Burchard, H., \& Bolding, K. (2002). GETM - a general estuarine transport model. Scientific Documentation. Technical report EUR 20253 en. In: Tech. Rep. European Commission.

Carstensen, J., Andersen, J. H., Gustafsson, B. G., \& Conley, D. J. (2014). Deoxygenation of the baltic sea during the last century. Proceedings of the National Academy of Sciences of the United States of America, 111(15), 5628-5633. https://doi.org/10.1073/pnas.1323156111

Csanady, G. T. (1981). Circulation in the Coastal Ocean. Advances in Geophysics, 23(C), 101-183. https://doi.org/10.1016/S0065-2687(08)60331-3

Dargahi, B. (2019). Dynamics of vortical structures in the Baltic Sea. Dynamics of Atmospheres and Oceans, 88,101117 . https://doi.org/10.1016/j.dynatmoce.2019.101117

Davis, R. E. (2010). On the coastal-upwelling overturning cell. Journal of Marine Research, 68(3-4), 369-385. https://doi.org/10.1357/002224010794657173

Döös, K., Meier, H. E. M., \& Döscher, R. (2004). The Baltic Haline Conveyor Belt or The Overturning Circulation and Mixing in the Baltic. AMBIO: A Journal of the Human Environment, 33(4), 261-266. https://doi.org/10.1579/0044-7447-33.4.261

Ekman, V. W. (1905). On the influence of the earth's rotation on ocean currents. Arkiv. Mat., Astron. Fys., 11, 1-52.

Elken, J., Raudsepp, U., \& Lips, U. (2003). On the estuarine transport reversal in deep layers of the Gulf of Finland. Journal of Sea Research, 49(4), 267-274. https://doi.org/10.1016/S13851101(03)00018-2

Geyer, W. R., \& MacCready, P. (2014). The Estuarine Circulation. Annual Review of Fluid Mechanics, 46(1), 175-197. https://doi.org/10.1146/annurev-fluid-010313-141302

Giddings, S. N., \& MacCready, P. (2017). Reverse Estuarine Circulation Due to Local and Remote Wind Forcing, Enhanced by the Presence of Along-Coast Estuaries. Journal of Geophysical Research: Oceans, 122(12), 10184-10205. https://doi.org/10.1002/2016JC012479

Gilcoto, M., Largier, J. L., Barton, E. D., Piedracoba, S., Torres, R., Graña, R., Alonso-Pérez, F., Villacieros-Robineau, N., \& de la Granda, F. (2017). Rapid response to coastal upwelling in a 
semienclosed bay. Geophysical Research Letters, 44(5), 2388-2397. https://doi.org/10.1002/2016GL072416

Golenko, M., Krayushkin, E., \& Lavrova, O. (2017). Современные проблемы дистанционного зондирования Земли из космоса. Current Problems in Remote Sensing of the Earth from Space., 280-296. https://doi.org/10.21046/2070-7401-2017-14-7-280-296

Hagen, E., \& Feistel, R. (2004). Observations of low-frequency current fluctuations in deep water of the Eastern Gotland Basin/Baltic Sea. Journal of Geophysical Research: Oceans, 109(C3). https://doi.org/10.1029/2003JC002017

Hagen, Eberhard, \& Feistel, R. (2007). Synoptic changes in the deep rim current during stagnant hydrographic conditions in the Eastern Gotland Basin, Baltic Sea. Oceanologia, 49(2), 185-208.

Hersbach, H., Bell, B., Berrisford, P., Hirahara, S., Horányi, A., Muñoz-Sabater, J., Nicolas, J., Peubey, C., Radu, R., Schepers, D., Simmons, A., Soci, C., Abdalla, S., Abellan, X., Balsamo, G., Bechtold, P., Biavati, G., Bidlot, J., Bonavita, M., ... Thépaut, J.-N. (2020). The ERA5 global reanalysis. Quarterly Journal of the Royal Meteorological Society, 146(730), 1999-2049. https://doi.org/10.1002/QJ.3803

Hinrichsen, H. H., von Dewitz, B., \& Dierking, J. (2018). Variability of advective connectivity in the Baltic Sea. Journal of Marine Systems, 186, 115-122. https://doi.org/10.1016/j.jmarsys.2018.06.010

Holtermann, P. L., Prien, R., Naumann, M., Mohrholz, V., \& Umlauf, L. (2017). Deepwater dynamics and mixing processes during a major inflow event in the central Baltic Sea. Journal of Geophysical Research: Oceans, 122(8), 6648-6667. https://doi.org/10.1002/2017JC013050

Jakobsen, F., Hansen, I. S., Ottesen Hansen, N. E., \& Østrup-Rasmussen, F. (2010). Flow resistance in the Great Belt, the biggest strait between the North Sea and the Baltic Sea. Estuarine, Coastal and Shelf Science, 87(2), 325-332. https://doi.org/10.1016/j.ecss.2010.01.014

Janssen, F., Schrum, C., \& Backhaus, J. O. (1999). A climatological data set of temperature and salinity for the Baltic Sea and the North Sea. Deutsche Hydrographische Zeitschrift, 51(S9), 5245. https://doi.org/10.1007/BF02933676

Jedrasik, J., Cieślikiewicz, W., Kowalewski, M., Bradtke, K., \& Jankowski, A. (2008). 44 Years Hindcast of the sea level and circulation in the Baltic Sea. Coastal Engineering, 55(11), 849860. https://doi.org/10.1016/j.coastaleng.2008.02.026

Jędrasik, J., \& Kowalewski, M. (2019). Mean annual and seasonal circulation patterns and long-term variability of currents in the Baltic Sea. Journal of Marine Systems, 193, 1-26. https://doi.org/10.1016/j.jmarsys.2018.12.011

Jönsson, B., Döös, K., Nycander, J., \& Lundberg, P. (2008). Standing waves in the Gulf of Finland and their relationship to the basin-wide Baltic seiches. Journal of Geophysical Research, 113(C3), C03004. https://doi.org/10.1029/2006JC003862

Krayushkin, E., Lavrova, O., \& Strochkov, A. (2019). Application of GPS/GSM Lagrangian minidrifters for coastal ocean dynamics analysis. Russian Journal of Earth Sciences, 19(1). 
Leppäranta, M., \& Myrberg, K. (2009). Circulation. In Physical Oceanography of the Baltic Sea (pp. 131-187). Springer Berlin Heidelberg. https://doi.org/10.1007/978-3-540-79703-6_5

801

802

803

804

805

806

807

808

809

810

811

812

813

814

815

816

817

818

819

820

821

822

823

824

825

826

827

828

829

830

831

832

833

834
Liblik, T., Laanemets, J., Raudsepp, U., Elken, J., \& Suhhova, I. (2013). Estuarine circulation reversals and related rapid changes in winter near-bottom oxygen conditions in the Gulf of Finland, Baltic Sea. Ocean Science, 9, 917-930.

Liblik, T., Naumann, M., Alenius, P., Hansson, M., Lips, U., Nausch, G., Tuomi, L., Wesslander, K., Laanemets, J., \& Viktorsson, L. (2018). Propagation of Impact of the Recent Major Baltic Inflows From the Eastern Gotland Basin to the Gulf of Finland. Frontiers in Marine Science, 5 , 222. https://doi.org/10.3389/fmars.2018.00222

Liblik, T., Väli, G., Lips, I., Lilover, M.-J., Kikas, V., \& Laanemets, J. (2020). The winter stratification phenomenon and its consequences in the Gulf of Finland, Baltic Sea. Ocean Science, 16, 1475-1490.

Lilover, M.-J., Elken, J., Suhhova, I., \& Liblik, T. (2017). Observed flow variability along the thalweg, and on the coastal slopesof the Gulf of Finland, Baltic Sea. Estuarine, Coastal and Shelf Science, 195, 23-33.

Lilover, M.-J., Pavelson, J., \& Kõuts, T. (2011). Wind forced currents over the shallow naissaar Bank in the Gulf of Finland. In Boreal environment research (Vol. 16).

Longdill, P. C., Healy, T. R., \& Black, K. P. (2008). Transient wind-driven coastal upwelling on a shelf with varying width and orientation. New Zealand Journal of Marine and Freshwater Research, 42(2), 181-196. https://doi.org/10.1080/00288330809509947

Macdonald, A. M. (1998). The global ocean circulation: a hydrographic estimate and regional analysis. Progress in Oceanography, 41(3), 281-382. https://doi.org/10.1016/S00796611(98)00020-2

Matthäus, W., \& Franck, H. (1992). Characteristics of major Baltic inflows-a statistical analysis. Continental Shelf Research, 12(12), 1375-1400. https://doi.org/doi:10.1016/02784343(92)90060-W

McDougall, T. J., \& Barker, P. M. (2011). Getting started with TEOS-10 and the Gibbs Seawater (GSW) Oceanographic Toolbox. SCOR/IAPSO WG127, 28pp. https://doi.org/ISBN 978-0-646$55621-5$

Meier, H. E. . (2007). Modeling the pathways and ages of inflowing salt- and freshwater in the Baltic Sea. Estuarine, Coastal and Shelf Science, 74(4), 610-627. https://doi.org/10.1016/J.ECSS.2007.05.019

Mohrholz, V. (2018). Major Baltic Inflow Statistics - Revised. Frontiers in Marine Science, 5, 384. https://doi.org/10.3389/fmars.2018.00384

Ollitrault, M., \& Rannou, J.-P. (2013). ANDRO: An Argo-based deep displacement dataset. https://doi.org/http://doi.org/10.17882/47077 
Placke, M., Meier, H. E. M., Gräwe, U., Neumann, T., Frauen, C., \& Liu, Y. (2018). Long-Term Mean Circulation of the Baltic Sea as Represented by Various Ocean Circulation Models. Frontiers in Marine Science, 5(SEP), 287. https://doi.org/10.3389/fmars.2018.00287

Rasmus, K., Kiirikki, M., \& Lindfors, A. (2015). Long-term field measurements of turbidity and current speed in the Gulf of Finland leading to an estimate of natural resuspension of bottom sediment. Boreal Environment Research , 20, 735-747. http://www.borenv.net/BER/pdfs/ber20/ber20-735.pdf

Reissmann, J. H., Burchard, H., Feistel, R., Hagen, E., Lass, H. U., Mohrholz, V., Nausch, G., Umlauf, L., \& Wieczorek, G. (2009). Vertical mixing in the Baltic Sea and consequences for eutrophication - A review. In Progress in Oceanography (Vol. 82, Issue 1, pp. 47-80). https://doi.org/10.1016/j.pocean.2007.10.004

Rubio, A., Gomis, D., Jordà, G., Espino, M., Rubio, A., Gomis, D., Jordà, G., \& Espino, M. (2009). Estimating geostrophic and total velocities from CTD and ADCP data: Intercomparison of different methods. JMS, 77(1), 61-76. https://doi.org/10.1016/J.JMARSYS.2008.11.009

Scully, M. E. (2016). Mixing of dissolved oxygen in Chesapeake Bay driven by the interaction between wind-driven circulation and estuarine bathymetry. Journal of Geophysical Research: Oceans, 121(8), 5639-5654. https://doi.org/10.1002/2016JC011924

Siiriä, S., Roiha, P., Tuomi, L., Purokoski, T., Haavisto, N., \& Alenius, P. (2019). Applying arealocked, shallow water Argo floats in Baltic Sea monitoring. Journal of Operational Oceanography, 12(1), 58-72. https://doi.org/10.1080/1755876X.2018.1544783

Sokolov, A., \& Chubarenko, B. (2012). Wind Influence on the Formation of Nearshore Currents in the Southern Baltic: Numerical Modelling Results. Archives of Hydroengineering and Environmental Mechanics, 59(1-2), 37-48. https://doi.org/10.2478/v10203-012-0003-3

Soomere, T., \& Keevallik, S. (2001). Anisotropy of moderate and strong winds in the Baltic Proper. In Proc. Estonian Acad. Sci. Eng (Vol. 7, Issue 1). http://kirj.ee/public/va_te/t50-1-3.pdf

Suhhova, I., Liblik, T., Lilover, M.-J., \& Lips, U. (2018). A descriptive analysis of the linkage between the vertical stratification and current oscillations in the Gulf of Finland. Boreal Environment Researchesearch, 23, 83-103.

Suhhova, I., Pavelson, J., \& Lagemaa, P. (2015). Variability of currents over the southern slope of the Gulf of Finland. Oceanologia, 57(2), 132-143. https://doi.org/10.1016/j.oceano.2015.01.001

Umlauf, L., Arneborg, L., Umlauf, L., \& Arneborg, L. (2009). Dynamics of Rotating Shallow Gravity Currents Passing through a Channel. Part I: Observation of Transverse Structure. Journal of Physical Oceanography, 39(10), 2385-2401. https://doi.org/10.1175/2009JPO4159.1

Umlauf, L., \& Burchard, H. (2005). Second-order turbulence closure models for geophysical boundary layers. A review of recent work. Continental Shelf Research, 25, 795-827. https://doi.org/10.1016/j.csr.2004.08.004

Väli, G., Meier, H. E. M., \& Elken, J. (2013). Simulated halocline variability in the Baltic Sea and its impact on hypoxia during 1961-2007. Journal of Geophysical Research: Oceans, 118(12), 
Villacieros-Robineau, N., Herrera, J. L., Castro, C. G., Piedracoba, S., \& Roson, G. (2013). de Vigo, NW Spain). Continental Shelf Research, 68, 67-79. https://doi.org/10.1016/j.csr.2013.08.017

Wu, H., Deng, B., Yuan, R., Hu, J., Gu, J., Shen, F., Zhu, J., Zhang, J., Wu, H., Deng, B., Yuan, R., Hu, J., Gu, J., Shen, F., Zhu, J., \& Zhang, J. (2013). Detiding Measurement on Transport of the Changjiang-Derived Buoyant Coastal Current. Journal of Physical Oceanography, 43(11), 2388-2399. https://doi.org/10.1175/JPO-D-12-0158.1

Wu, J. (1980). Wind-Stress coefficients over Sea surface near Neutral Conditions-A Revisit. Journal of Physical Oceanography, 10(5), 727-740. https://doi.org/10.1175/15200485(1980)0102.0.co;2

Zhurbas, V., Elken, J., Paka, V., Piechura, J., Väli, G., Chubarenko, I., Golenko, N., \& Shchuka, S. (2012). Structure of unsteady overflow in the supsk furrow of the baltic sea. Journal of Geophysical Research: Oceans, 117(4), 4027. https://doi.org/10.1029/2011JC007284

Zhurbas, V., Väli, G., Golenko, M., \& Paka, V. (2018). Variability of bottom friction velocity along the inflow water pathway in the Baltic Sea. Journal of Marine Systems, 184, 50-58. https://doi.org/10.1016/J.JMARSYS.2018.04.008 northeastern Baltic Proper: Results of very high-resolution modelling for summer season. Oceanologia. https://doi.org/10.1016/J.OCEANO.2021.08.003 